\title{
HUMAN SOULS AS CONSUBSTANTIAL SONS OF GOD: THE HETERODOX ANTHROPOLOGY OF LEONTIUS OF JERUSALEM
}

\author{
Dirk Krausmüller (KrausmullerD@ cardiff.ac.uk)
}

\begin{abstract}
In his treatise Contra Nestorianos Leontius of Jerusalem refers to the human soul as "divine inbreathing", which he understands as a consubstantial emanation from God. This paper argues that Leontius was confronted with the Nestorian claim that a composition between an uncreated and a created entity is impossible and that he refuted this claim by arguing that the soul is divine and that the composition of a human soul with a human body is therefore a strict parallel for the incarnation. One of Leontius' starting points was the traditional view that Adam's soul was endowed with the Holy Spirit and not merely with a derivative grace. This model had the advantage that it located "God" in the human being but the disadvantage that this presence remained extrinsic to the human compound. To make it function as a precedent for the Incarnation Leontius substituted the Son for the Spirit and reduced the human nature to the body thereby indicating that the soul must be equated with the divine Son. In order to distinguish the case of Christ from that of Adam and other human beings he employed the Biblical motif of the "pledge", which was traditionally used to contrast the partial spiritual endowment of the believers in this world with their complete spiritual endowment in the world to come but which he now applied to Adam and Christ. This permitted him to claim that in Adam the Son was only partially present while in Christ he was present completely. Thus he conceptualised the Incarnation not as the composition of the divine Word with a human nature consisting of body and soul but as a composition of the divine Word as soul and a human body. Consequently the divine component of traditional Christology could no longer be given a satisfactory role in the salvation of humankind. One reason for this shift, it is argued in this paper, was a too great dependence on the conceptual framework of his Nestorian opponent whose focus had been on the endowment of the human being Jesus with the Holy Spirit, who thus assumed a crucial role in the incarnation. Leontius accepted this framework as well as the Nestorian custom to see the difference between the Spirit in Jesus and the Spirit in other human beings in quantitative terms, and merely modified it by identifying the Holy Spirit with the Son on the one hand and with the soul on the other. However, it is suggested in this paper, Leontius may have believed in the divinity and timelessness of the soul independently of his Nestorian opponent. His interpretation of Philippians 2:6-7 suggests that he was a latter-day Origenist who could express his ideas more freely than his forebears because the political circumstances of the early seventh century made enforcement of orthodoxy impossible in the Eastern provinces.
\end{abstract}

Dirk Krausmüller, "Human Souls as Consubstantial Sons of God: The Heterodox Anthropology of Leontius of Jerusalem," in: Journal for Late Antique Religion and Culture 4 (2010) 43-67; ISSN: 1754-517X; Website: http://www.cardiff.ac.uk/clarc/jlarc 
The Chalcedonian theologian Leontius of Jerusalem is today best known for his contributions in the field of Christology, and Christological issues are indeed the raison d'etre of his surviving works: the two treatises that bear his name defend the Creed of Chalcedon and Constantinople II against Nestorian and Monophysite attacks. ${ }^{1}$ Thus it is not surprising that modern scholars have focused on Leontius' definitions of the concepts "nature", "hypostasis" and "composition" and attempted to establish whether these definitions help to clarify the doctrine formulated at the two councils. ${ }^{2}$ However, exclusive focus on such a narrow range of topics runs the danger of obscuring the richness of Leontius' theological speculation. Close reading of Contra Nestorianos, the longest of his extant treatises, reveals that his search for effective arguments leads him to other aspects of the Christian belief system and that his views on such aspects are highly original and often irreconcilable with the Patristic consensus that had been established in the fourth and fifth centuries.

In a recent article I have argued that Leontius used the Christological model that he had developed as a blueprint for a radical reorganisation of the Trinity, with the result that the Trinity is no longer regarded as a timeless framework within which the event of the incarnation takes place, but is rather seen as the result of a previous act of divine self-constitution. ${ }^{3}$ In this article I shift the focus to Leontius' anthropology, which plays an important role in his attempts to prove that the incarnation must be conceived of as a composition of the divine nature and the human nature in the hypostasis of the divine Word and to rebut the claims of his Nestorian adversary that such an understanding of the incarnation was neither necessary nor indeed possible.

Leontius repeatedly points out that the human being is also a composite made up of two elements, body and soul, which are substantially different from each other. Such use of the so-called anthropological paradigm had a long and distinguished history. ${ }^{4}$ However, it was not without problems since it glossed over the fact that in the case of Christ an uncreated and a created entity enter into a composition whereas in the case of the human being both components are created. If Leontius had merely followed established tradition we would need to conclude that his arguments fail to address the central Nestorian objection that the defenders of Chalcedon and Constantinople II cannot offer valid analogies for their understanding of the incarnation. However, in-depth analysis of Contra Nestorianos suggests that this is not the case and that Leontius sets out a radically different model according to which the soul is divine in the strict sense of the word and has a genetic relationship with the divinity as its progenitor in very much the same way as the divine Son does.

\footnotetext{
${ }^{1}$ Leontius of Jerusalem, Capita triginta contra Monophysitas, PG 86, 1769-1901 (CPG 6917); Contra Nestorianos, PG 86, 1399-1768i (CPG 6918), in the following abbreviated to $C N$.

${ }^{2}$ See A. Grillmeier, Jesus der Christus im Glauben der Kirche, vol. 2, pt. 2: Die Kirche von Konstantinopel im 6. Jahrhundert (Freiburg, Basel, Wien, 1989), pp. 291-328, with a survey of earlier secondary literature. See also C. dell'Orso, Cristo e Logos. Il calcedonesimo del VI secolo in oriente (Rome 2010), pp. 348-73.

${ }^{3}$ See my article "Divine self-invention: Leontius of Jerusalem's reinterpretation of the Patristic model of the Christian God," Journal of Theological Studies, 57 (2006), pp. 526-45.

${ }^{4}$ See e.g. F. Gahbauer, Das anthropologische Modell. Ein Beitrag zur Christologie der frühen Kirche bis Chalcedon (Würzburg, 1984).

Dirk Krausmüller, "Human Souls as Consubstantial Sons of God: The Heterodox Anthropo-

logy of Leontius of Jerusalem," in: Journal for Late Antique Religion and Culture 4 (2010) 43-67; ISSN: 1754-517X; Website: http://www.cardiff.ac.uk/clarc/jlarc
} 
It is evident that this interpretation of the anthropological paradigm permits a much more effective proof than the conventional version. Yet this advantage comes at a high cost because Leontius' position is completely at odds with established doctrine. In the last part of my article I will make the case that Leontius started from the Origenist notion of the soul of Christ, which is consubstantial with all other souls, but that he then identified this soul with the divinity of the Son as one part of the composite Christ, with the consequence that all other souls were also elevated to the status of divine beings; and I will further discuss why he could voice such startlingly heterodox ideas only a few decades after Origenism had been declared a heresy.

Unlike Leontius' speculation about the Trinity, which is set out concisely and unequivocally in a single chapter of Contra Nestorianos, his views on the human soul must be gleaned from a number of passages most of which make use of terminology that is open to interpretation. Therefore I shall look at all available evidence and assess in each case whether statements that characterise the soul as divine should be taken seriously or whether they should not rather be dismissed as rhetorical flourishes. And I shall further ask what implications either of these possible interpretations would have for the Christological argument, which the anthropological paradigm is intended to support.

The first passage I would like to consider is chapter seven of the first book of Contra Nestorianos. As is his wont Leontius first quotes a passage from a lost Nestorian treatise, which challenges the Chalcedonian concept of a hypostatic union of God and man in the incarnated Christ, and then proceeds to its refutation. In this case the Nestorian bases his argument on the axiomatic statement that "the difference between what is uncreated and what is created prevents naturally the

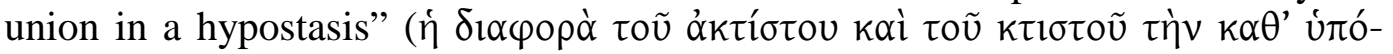
$\left.\sigma \tau \alpha \sigma l v ~ \varphi v \sigma l k \tilde{\omega} \zeta \kappa \omega \lambda u_{\varepsilon l} \varepsilon{ }^{\prime} \nu \omega \sigma l v\right){ }^{5}$ Leontius' response reads as follows:

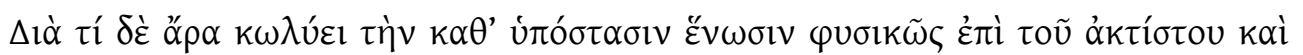

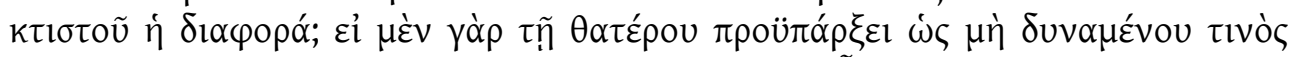

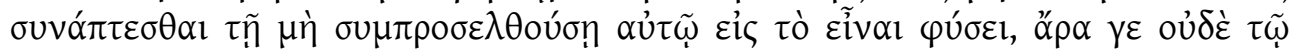

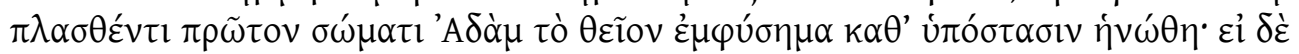

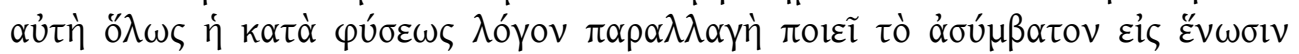

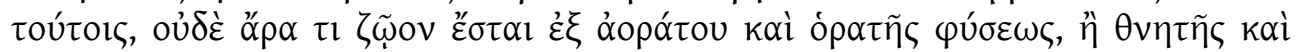

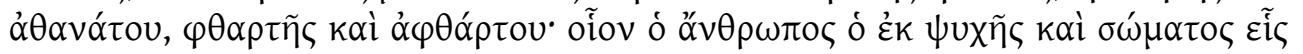

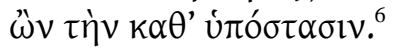

"Why then does the difference between what is uncreated and what is created prevent naturally the union in a hypostasis? If it (sc. prevented it) because of the preexistence of one part as if something could not be connected with a nature that does not come into being together with it, then the divine inbreathing, too, would not have been united in a hypostasis with the body of Adam, which had been fashioned first; and if the very difference in the definition of nature by itself causes their inability to come together in a union, then there would also be no living being made up of an invisible and a visible nature, or of a mortal and an immortal one, or of a corruptible

\footnotetext{
${ }^{5} C N, \mathrm{I} .27, P G, 86,1493 \mathrm{~A} 9-10$.

${ }^{6} C N$, I.27, $P G, 86,1493 \mathrm{~B} 4-12$.

Dirk Krausmüller, "Human Souls as Consubstantial Sons of God: The Heterodox Anthropology of Leontius of Jerusalem," in: Journal for Late Antique Religion and Culture 4 (2010) 43-67; ISSN: 1754-517X; Website: http://www.cardiff.ac.uk/clarc/jlarc
} 
and an incorruptible one, as for example the human being made up of soul and body, which is one as regards the hypostasis."

In this passage Leontius identifies two reasons that might have prompted his adversary to formulate his axiom that an uncreated nature cannot be compounded with a created nature. The first is that the two parts did not come into existence simultaneously at the moment of their composition, the second that they differ in their natural make-up. Accordingly his counter-argument is an attempt to show that these facts are no obstacles to a hypostatic union. In order to achieve his aim he twice has recourse to the anthropological paradigm. In the first case he points out that Adam's body had already been created before it was hypostatically united with the vivifying breath of God; and in the second case he argues that body and soul form a single hypostasis despite possessing diametrically opposite qualities.

It is immediately evident that this strategy is far from persuasive. The second argument seems to miss the crucial point: the Nestorian had not maintained that any difference in nature was an obstacle to a union, but had focused on the specific difference between created and uncreated being. However, according to official doctrine the human soul was a creature just like the human body. And the first argument appears to be even weaker: while Adam's body may have been created before it became ensouled, it had obviously only existed for a short time and can therefore not serve as a genuine parallel for the eternal divine Word that assumed the flesh. Moreover, the human body belongs to the material sphere and is therefore even less like the divine Word than the immaterial human soul. It is evident that the parallel would have been much closer if Leontius had set out a scenario where the soul pre-exists the body. And this is in fact what he has done in the previous chapter: there he uses the union of the disembodied souls with their resurrected bodies as a parallel for the union of the pre-existing Word with the flesh. ${ }^{7}$ Even this analogy, however, is not perfect because in this case the bodies are not created but re-created and had formerly been united with the souls.

As contemporary readers would undoubtedly have known there existed a further scenario that provided a much closer match for the incarnation: according to this scenario Adam's soul had already existed before its initial union with the body. Yet the same readers would also have been aware that this alternative was no longer viable after the condemnation of Origen at the Second Council of Constantinople in 553.

Since Leontius studiously avoids any reference to the pre-existence of the soul, one might conclude that he toed the official line. Indeed, the statement that "the divine inbreathing was united in a hypostasis with the body of Adam that had been

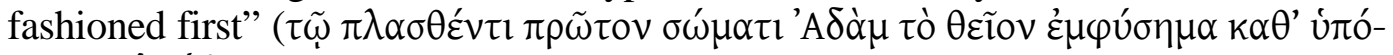
$\sigma \tau \alpha \sigma l v \dot{\eta} v(\dot{\theta} \eta)$ appears to be deliberately anti-Origenist. At the time when Leontius wrote his treatise it was staunch Nestorians such as Babai the Great who insisted on the pre-existence of the body whereas theologians with Origenist leanings such as Maximus the Confessor claimed that body and soul were created simultaneously. ${ }^{8}$ However, Leontius' statement is less clear-cut than it first seems. Unlike Babai

\footnotetext{
${ }^{7} \mathrm{CN}$ I.26, $P G, 86,1492 \mathrm{D} 10-14$.

${ }^{8}$ See Babai the Great, Liber de Unione, c. 10, tr. A. A. Vaschalde (CSCO, 80, Scriptores Syri, 35; Leuven, 1953), p. 90, 11. 1-4: Scriptura nobis exposuit illum primum in omnibus membris suis Dirk Krausmüller, "Human Souls as Consubstantial Sons of God: The Heterodox Anthropology of Leontius of Jerusalem," in: Journal for Late Antique Religion and Culture 4 (2010) 43-67; ISSN: 1754-517X; Website: http://www.cardiff.ac.uk/clarc/jlarc
} 
the Great who states unequivocally in his Liber de Unione that Adam's soul was created in the pre-existing body he merely speaks of the endowment of Adam's body with the soul. Moreover, he expresses this notion in a rather idiosyncratic manner. Taking as his starting point Genesis 2:7: "and God formed man as dust from the earth and breathed into his face a breath of life and man was turned into a

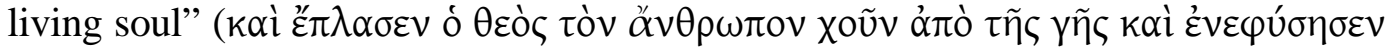

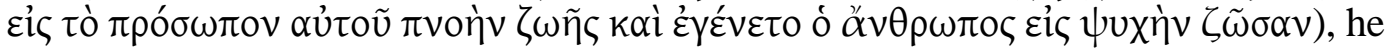
rephrases this verse in such a way that it now corresponds to traditional definitions of the human being as "the soul ... that has been united in a hypostasis with the

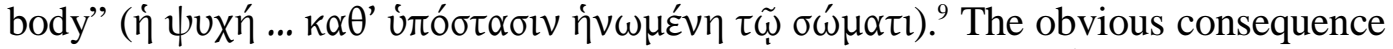
of this reformulation is the replacement of "the soul" ( $\dot{\eta} \psi v x \eta ́$ ) with "the divine

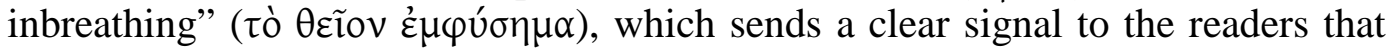
these two terms refer to one and the same reality.

Leontius makes this substitution without further ado and thus gives the impression that what he says is completely above board. However, there can be no doubt that it would have been roundly rejected in the theological circles to which Leontius' Nestorian adversary belonged. Representatives of the Antiochene tradition such as Diodore of Tarsus, John Chrysostom and Theodoret of Cyrus had made a careful distinction between the "inbreathing" and the human soul, which they considered to be created out of nothing, and Babai the Great was still propounding this position at the beginning of the seventh century when he stated in his Liber de Unione that "the angels ... realised that God who breathed into Adam and created the soul ... had created for them, too, rational life out of nothing" (angeli ... intellexerunt quod Deus, qui in Adam inspiravit et creavit animam ... etiam ipsis creavit vitam rationalem ex nihilo). ${ }^{10}$ These authors were clearly troubled by the fact that Genesis 2:7 does not clearly distinguish between God's act of breathing into Adam's face and the presence in Adam of a soul as its result and therefore took great pains to read this distinction into the text. In the fourth century Diodore of Tarsus averred that Moses "says that the divine inbreathing is the creative cause of it (sc. of the soul)"

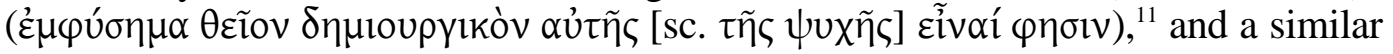
position is still expressed in a Pseudo-Athanasian text from the seventh or eighth century, the Liber de Definitionibus, which states that "the inbreathing created a

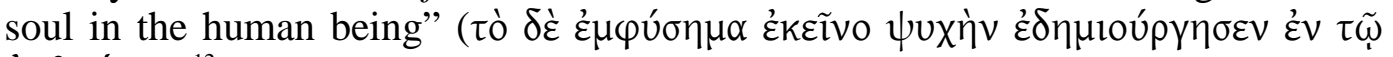

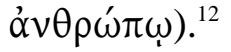

Leontius evidently takes the diametrically opposite approach when he identifies the two terms. What are the implications of such a move? The Antiochene authors whom I have just mentioned state that they responded to exegetes who concluded from the ambiguous wording of Genesis 2:7 "that the divine inbreathing had be-

formatum et corporatum fuisse, et deinde exposuit creationem animae in eo; and Maximus, Ambigua, $P G, 91,1321 \mathrm{D}-1325 \mathrm{C}$.

${ }^{9}$ Anastasius the Sinaïte, Capita vi adversus monotheletas, 9.1, ed. K.-H. Uthemann, Anastasii Siinaitae sermones duo in constitutionem hominis secundum imaginem Dei necnon opuscula adversus monotheletas (Corpus Christianorum, Series Graeca, 12; Turnhout, 1985).

${ }^{10}$ Babai the Great, Liber de Unione, ch. 10, tr. A. Vaschalde, p. 90, 11. 17-21.

${ }^{11}$ Catenae Graecae in Genesim et Exodum, II, Collectio Coisliniana in Genesim, ed. F. Petit (Corpus Christianorum, Series graeca, 15, Turnhout, Leuven, 1986), * 83 (Diodore), p. 86, 11. 9-12.

${ }^{12}$ Pseudo-Athanasius, Liber de definitionibus, ch. 7, PG, 28, 545D7-10.

Dirk Krausmüller, "Human Souls as Consubstantial Sons of God: The Heterodox Anthropo-

logy of Leontius of Jerusalem," in: Journal for Late Antique Religion and Culture 4 (2010) 43-67; ISSN: 1754-517X; Website: http://www.cardiff.ac.uk/clarc/jlarc 
come the immortal soul" ( and Cyril of Alexandria who preferred to interpret the "inbreathing" as an additional endowment of the already complete human being Adam with the Holy Spirit also makes reference to the alternative view "that the inbreathing that had come forth from the divine substance ... became a soul for the living being" ( $\tau$ ò $\dot{\varepsilon} \kappa \tau \tilde{\eta} \varsigma$ $\theta \varepsilon i ́ \alpha \varsigma$

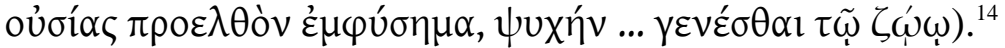

The advantages of such a position for a theologian in Leontius' situation are immediately obvious. If he had claimed that the soul was divine, he would have been able to counter his adversary's argument even more effectively than if he had had recourse to a model according to which the soul pre-existed the body, but was nevertheless a created being. Since countless human souls are hypostatically united with created material bodies, there could then be no conceivable reason why a hypostatic union between an uncreated and a created being should be impossible in the specific case of the divine Word.

However, is this really the message that Leontius wishes to convey? At first sight this seems utterly out of the question. After all, belief in the soul's full divinity, as expressed in Pseudo-Justin's De Resurrectione where the soul is called "part ... and

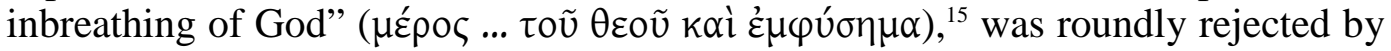
mainstream Christians, not only because it blurred the difference between creator and creation but also because it made God subject to division and change.

Therefore one might be tempted to conclude that Leontius applied the term "inbreathing" ( $\varepsilon \mu \varphi v ́ \sigma \eta \mu \alpha)$ to the soul in a much vaguer fashion that did not call into question its status as a creature, especially since there were respectable precedents for such use: Cyril of Alexandria, for example, characterises the soul as "image and

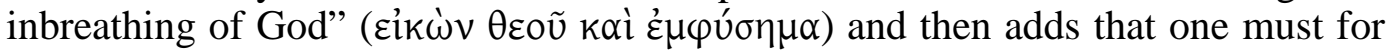

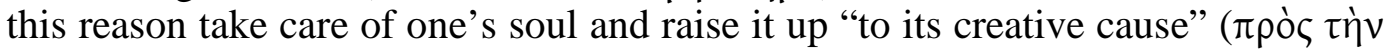

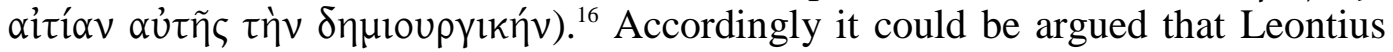
held the same view as Cyril and the absence of a similar corrective in his text could be explained through a lack of awareness of the problems arising from a straightforward equation of the divine inbreathing and the human soul. If this were the case we would need to return to our original assessment of the passage and would be forced to conclude that the arguments put forward by Leontius fail to address the issues raised by his Nestorian adversary.

There is only one way to establish which of the two proposed interpretations is correct: we need to analyse further passages in Contra Nestorianos where Leontius sets out his views about the origin of the human soul. The first passage which I will consider is found in the first chapter of book one, where Leontius is confronted with the Nestorians' claim that the soul as part of the human composite is by necessity itself made up of parts. In order to refute this claim Leontius points out that if this were true for "that which is intelligible and spiritual and like to angels and furthermore also in the image of God and an inbreathing of the glory of the almighty"

\footnotetext{
${ }^{13}$ Catenae Graecae in Genesim et Exodum, II, ed. Petit, * 83 (Diodore), p. 86, 11. 2-3.

${ }^{14}$ Cyril of Alexandria, In D. Joannis Evangelium, ed. E. Pusey, 3 vols (Oxford, 1872), II, p. 485, 11. 14-15.

${ }^{15}$ Pseudo-Justin, De resurrectione, $P G, 6,1588$ A3-4.

${ }^{16}$ Cyril of Alexandria, Die Matthäus-Kommentare aus der griechischen Kirche, ed. J. Reuss (TU, 61; Berlin, 1957), pp. 153-269, fragment, 81, 1. 7.

Dirk Krausmüller, "Human Souls as Consubstantial Sons of God: The Heterodox Anthropology of Leontius of Jerusalem," in: Journal for Late Antique Religion and Culture 4 (2010) 43-67; ISSN: 1754-517X; Website: http://www.cardiff.ac.uk/clarc/jlarc
} 


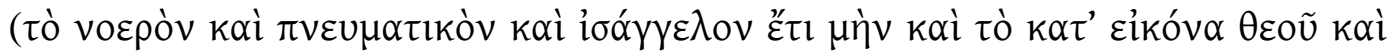

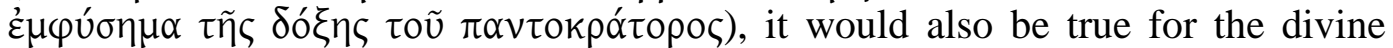
archetype, which then permits him to accuse his opponent of blasphemy. ${ }^{17}$

At first sight the characterisation of the human soul as "in the image of God"

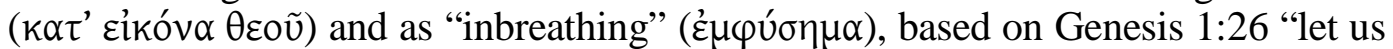

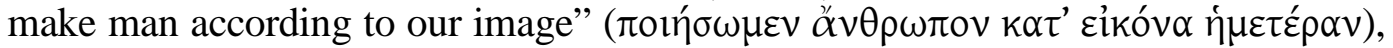
and on Genesis 2:7 "God ... breathed into his face the breath of life" (ó Өcó...

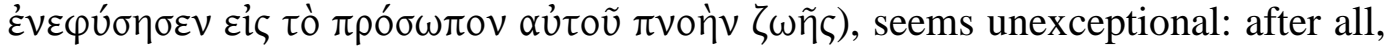
we have just come across the almost identical phrase "image and inbreathing of

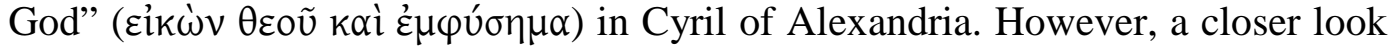
reveals that the two verses from Genesis are not the only Biblical passages to which Leontius makes reference because the qualification of the inbreathing as "of the glory of the almighty" ( $\tau \tilde{\eta} \varsigma ~ \delta o ́ \xi \eta \varsigma ~ \tau o \tilde{v} \pi \alpha \nu \tau o \kappa \rho \alpha ́ \tau o \rho \circ \varsigma$ ) is clearly based on the

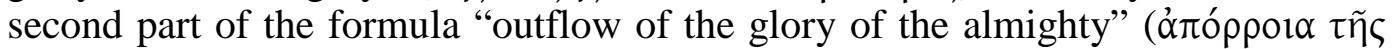

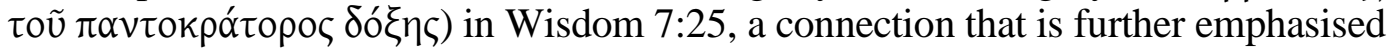

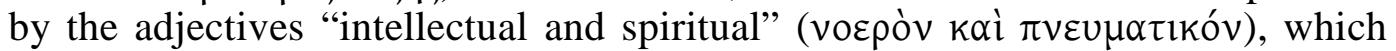

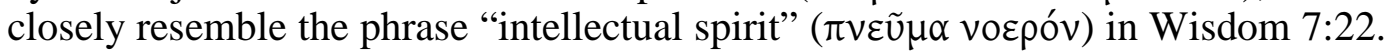

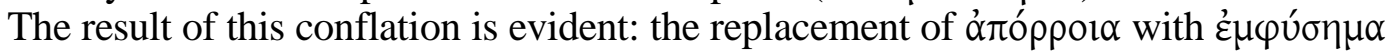
insinuates equivalence between the two terms, which can only mean that Leontius expects his readers not only to equate the soul with God's "inbreathing", but also to conceive of this inbreathing as an emanation of the divinity.

Does this additional evidence permit us to affirm that Leontius thought human souls to be fully divine? Unfortunately, the answer must still be no. Use of the term

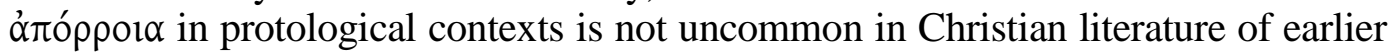
centuries. Gregory of Nyssa, for example, had referred to the mind as "the outflow

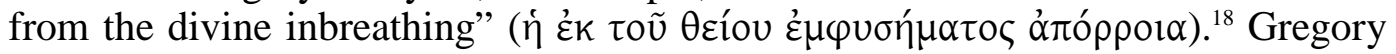
of Nazianzus had claimed that the human souls "were a part ... of God and had

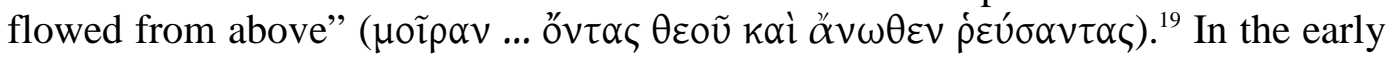
seventh century such phrases were, of course, considered unacceptable because of their Origenist overtones but this does not necessarily mean that they were intrinsically heretical: after all, neither of the two Cappadocian authors had ever believed that human souls were an effluence of the divine substance.

At this point one might therefore conclude that Leontius may well have held heterodox views about the origin of the soul but that the ambiguities inherent in the terms and concepts used by him make it impossible to arrive at any certainty. However, there are other passages in Contra Nestorianos where Leontius is less guarded and where he does indeed confirm that the souls are consubstantial with their "father" God. I will start the discussion with chapter nineteen of book four, which addresses the Nestorian claim that Mary cannot be called "God-bearer" because the Son of God is engendered by his consubstantial Father and can therefore not experience a second birth from a human mother in the incarnation. Leontius

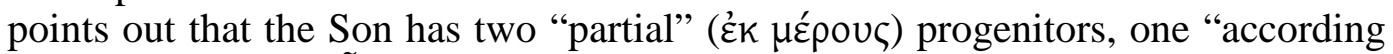

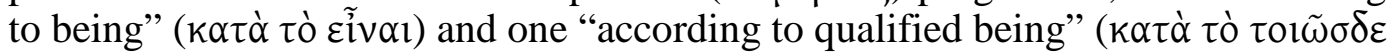

\footnotetext{
${ }^{17} C N$, I.1, PG, 86, 1405D-1408A.

${ }^{18}$ Gregory of Nyssa, Antirrheticus adversus Apollinarem, ed. F. Müller, Gregorii Nysseni Opera, III.1: Opera dogmatica minora, (Leiden, 1958), p. 146, 1. 26.

${ }^{19}$ Gregory of Nazianzus, De pauperum amore, $P G, 35,865 \mathrm{~B} 12$.

Dirk Krausmüller, "Human Souls as Consubstantial Sons of God: The Heterodox Anthropology of Leontius of Jerusalem," in: Journal for Late Antique Religion and Culture 4 (2010) 43-67; ISSN: 1754-517X; Website: http://www.cardiff.ac.uk/clarc/jlarc
} 
Ẽ⿱v$\alpha 1)$ when he becomes incarnated, and then proceeds to support his argument with the anthropological paradigm:

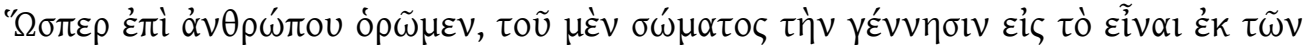

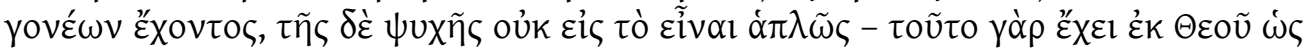

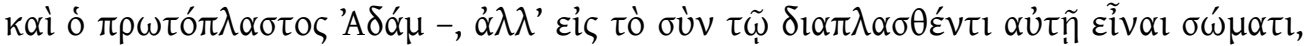

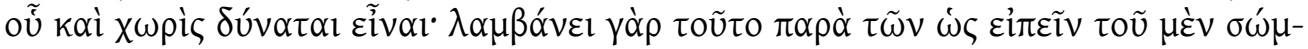

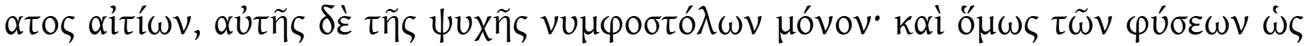

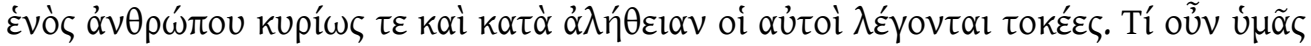

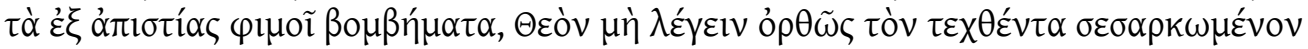

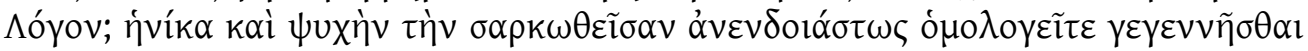

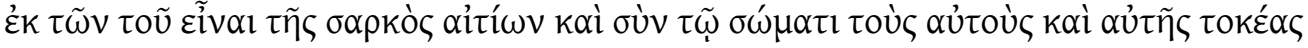
óvoứ̛́ $\varepsilon \tau \varepsilon ; 20$

"As we see with the human being who has from the parents the birth of the body into being whereas (sc. he has from them the birth) of the soul not simply into being - for it has this (sc. the being) from God, just as also the first-formed Adam -, but into being with the body that has been shaped for it, which (sc. the soul) can also be without, for he takes this from those who are so-to-speak the causes of the body, but only the escorts of the soul itself, and these same ones are nevertheless called properly and truly parents of the natures as of one human being. Why then do the buzzings arising from disbelief gag you so as not to say correctly that the born incarnated Word is God, when you admit without hesitation that the incarnated soul is born from the causes of the being of the flesh and you call the same together with the body also parents of it (sc. the soul)?"

Despite the convoluted phrasing the thrust of the argument is clear. Ordinary human beings are called mothers and fathers although strictly speaking they are only the causes for the "being" (Ẽ⿱v$\alpha$ l) of the bodies of their offspring whereas the

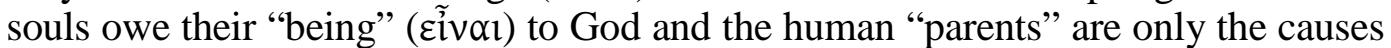
of the "qualified being" ( $\tau 01 \tilde{\omega} \sigma \delta \varepsilon \varepsilon \tilde{i} v \alpha l$ ) of souls insofar as they bring about their embodied state. Therefore Mary can justly be called "mother of God" despite the fact that she is only the cause for the "being" ( $\tilde{\tilde{I}} v \alpha \mathrm{l}$ ) of the Word's human body

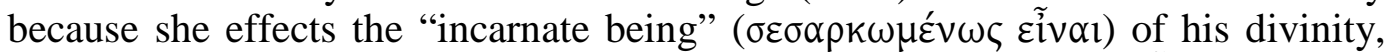

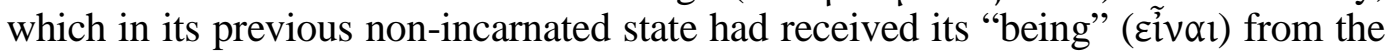
divine Father. It is evident that Leontius strives to create a close parallel between the two cases and that he achieves his aim by assimilating the human compound to the incarnated Word. This strategy results in an anthropology with a strongly heterodox flavour. For example, the distinction that he makes between the "soul as

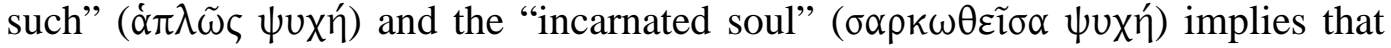
like the Word the disembodied soul existed before its composition with a body. Even more suggestive, however, is Leontius' claim that God is the cause of "being"

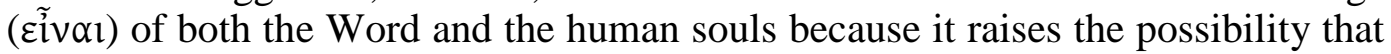
the two relationships are equivalent.

In order to establish whether this is indeed the case we need to turn to other arguments based on the anthropological paradigm. In chapter four of book three

\footnotetext{
${ }^{20} C N$, IV.19, $P G, 86,1685$ A12-B12.

Dirk Krausmüller, "Human Souls as Consubstantial Sons of God: The Heterodox Anthropo-

logy of Leontius of Jerusalem," in: Journal for Late Antique Religion and Culture 4 (2010) 43-67; ISSN: 1754-517X; Website: http://www.cardiff.ac.uk/clarc/jlarc
} 
Leontius applies the framework that we have just reconstructed to the specific case of Adam but with the added twist that the relationship between God and Adam's soul is now described in genetic terms:

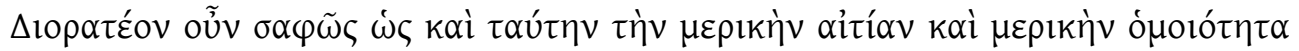

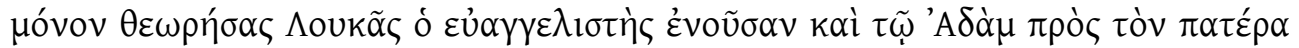

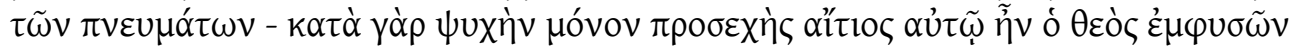

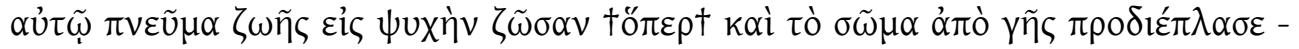

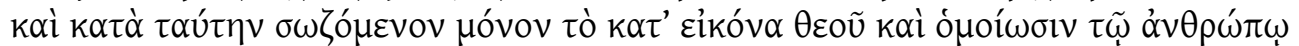

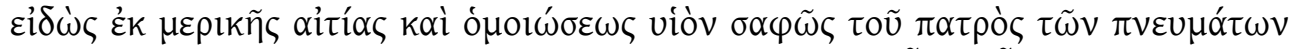

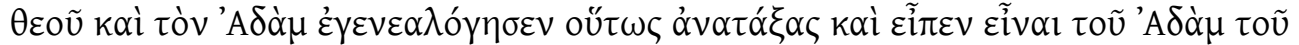

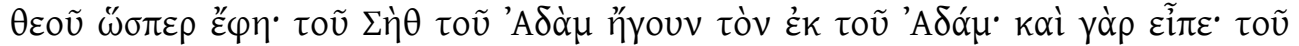

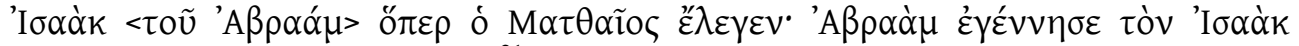

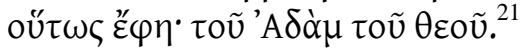

"One must, then, clearly see that Luke, too, only considered that partial cause and partial similarity with the father of the spirits to be inherent in Adam, too, - for only as regards the soul was God his direct cause by breathing into him spirit of life so as to be a living soul just as he also shaped beforehand the body from earth - and that he knew that only as regards this (sc. the soul) the divine image and likeness is preserved for the human being, when in a genealogy he clearly called Adam, too, the son of God 'the father of spirits', having thus arranged it, and when he said that he is 'Adam of God', just as he said 'Seth of Adam', that is to say: 'the one out of Adam', for he also said 'Isaac <of Abraham>', what Matthew expressed as 'Abraham begat Isaac'. In this way he said 'Adam of God'."

In this passage Leontius repeats his claim that God is the "direct cause" ( $\pi \rho \circ \sigma-$

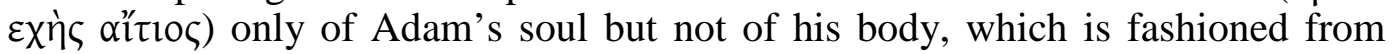
earth. ${ }^{22}$ However, this basic configuration is now elaborated through recourse to

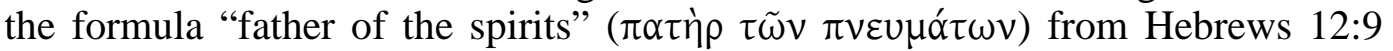
where "spirits" was traditionally understood to refer to human souls. ${ }^{23}$ Examination of the context shows that Leontius takes great pains to read this relationship into the Biblical text. Taking as his starting point Genesis 2:7: "he breathed into his face

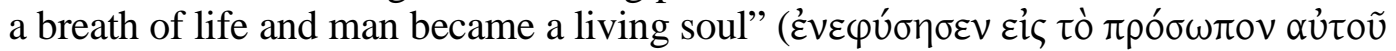

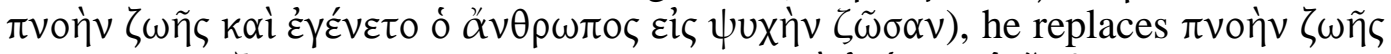

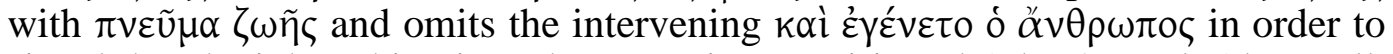
signal that the inbreathing is at the same time a spirit and Adam's soul. Above all, however, he consistently emphasises the genetic character of the relationship between God and human souls. This is already evident in his decision to complement the Biblical term "father" ( $\pi \alpha \tau \eta ́ \rho)$ with "son" (viós) and becomes even more ob-

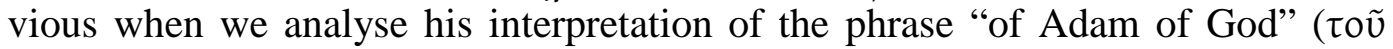

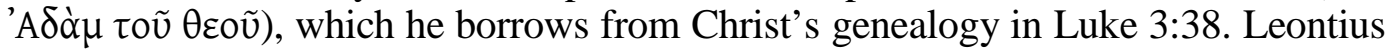
starts by pointing out that in Luke's text there is strict equivalence between the relationship between Adam and God on the one hand and the relationships between

\footnotetext{
${ }^{21}$ CN III, 4, 1612D-1613A.

${ }^{22}$ Since he states elsewhere in Contra Nestorianos that God created Adam's body directly and did not use nature as a mediator, we can rule out that this refers to the efficient cause.

${ }^{23}$ See e.g. Cyril of Alexandria, Commentary in Isaiam prophetam, PG, 70, 1276AB.

Dirk Krausmüller, "Human Souls as Consubstantial Sons of God: The Heterodox Anthropology of Leontius of Jerusalem," in: Journal for Late Antique Religion and Culture 4 (2010) 43-67; ISSN: 1754-517X; Website: http://www.cardiff.ac.uk/clarc/jlarc
} 
Christ's human ancestors on the other: in each case a simple genitive is used. In a

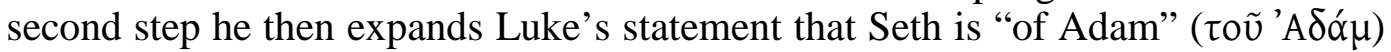

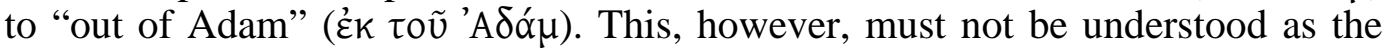
introduction of a distinction between human fathers and God as "father of spirits"

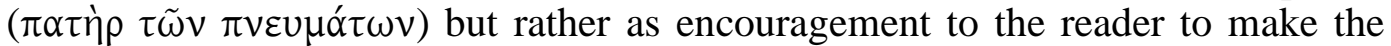
same modification in the parallel statement and to expand it to "Adam out of God"

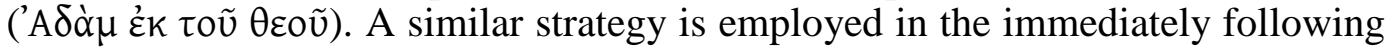
statement which creates a parallel between the genealogy in the Gospel of Luke and its counterpart in the Gospel of Matthew where the relationship between Christ's forefathers, the first of whom is in this case Abraham, is expressed through the verb "begat" ( $\left.\varepsilon^{\prime} \varepsilon^{\prime} \nu \nu \eta \sigma \varepsilon\right)$. Leontius points out that the statement "Isaac <of Abraham>"

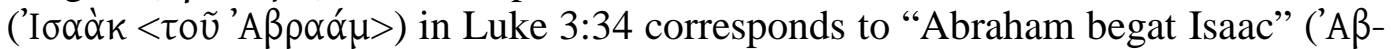

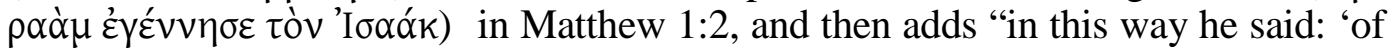

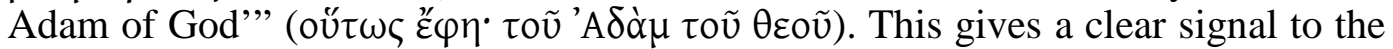

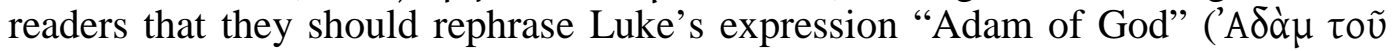
$\theta \varepsilon \circ \tilde{v})$, which does not have a counterpart in Matthew, as "God begat Adam" (o

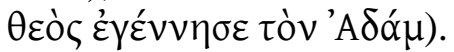

It goes without saying that this argument is problematic because according to Leontius the relationship between Adam and God is not identical with the relationships between Christ's human ancestors: as we have seen in the latter case the genetic link is limited to their bodies. However, this does not mean that we can simply dismiss it for it provides clear evidence for Leontius' belief that terms like

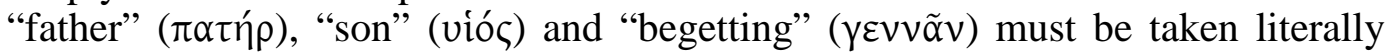
when they refer to God and Adam's soul. I would therefore argue that the phrase

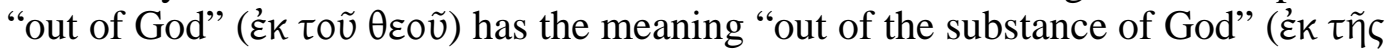

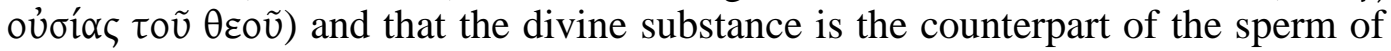
the father and the blood of the mother as the material causes of the bodies of their children.

In chapter four of book three Leontius does not use the term "consubstantiality"

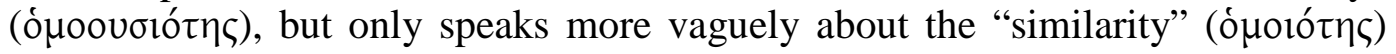
between God and the soul. However, analysis of the first chapter of the second book shows that he is not always so circumspect. There he is confronted with the axiom that "consubstantial beings do not wish to be consubstantial in part" ( $\tau \dot{\alpha}$

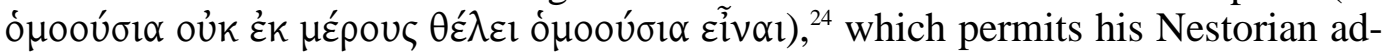
versary to reject the doctrine of a composite Christ who is consubstantial with the divine Father in his divinity and consubstantial with Mary in his humanity. In his refutation Leontius has again recourse to the anthropological paradigm:

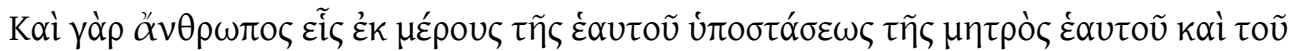

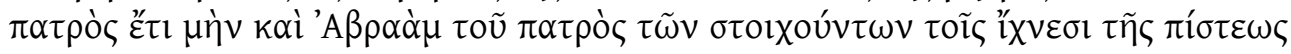

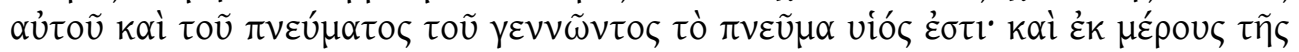

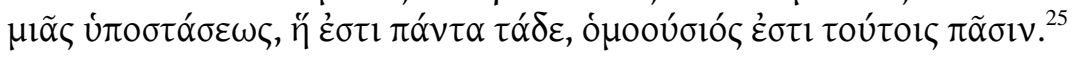

"For one human being is in part of his own hypostasis of his mother and his father, and also of Abraham, the father of those who follow the footsteps of faith, and of

\footnotetext{
${ }^{24} C N$, II.1, $P G, 86,1528 \mathrm{~A} 10-11$.

${ }^{25} C N$, II.1, $P G, 86,1536 \mathrm{C} 1-7$.

Dirk Krausmüller, "Human Souls as Consubstantial Sons of God: The Heterodox Anthropology of Leontius of Jerusalem," in: Journal for Late Antique Religion and Culture 4 (2010) 43-67; ISSN: 1754-517X; Website: http://www.cardiff.ac.uk/clarc/jlarc
} 
the spirit that begets the spirit, and he is in each part of the one hypostasis, which is all these, consubstantial with all those."

Here Leontius distinguishes between three different "progenitors" of a human being - the natural parents, Abraham as the father of the faithful, and "the spirit"

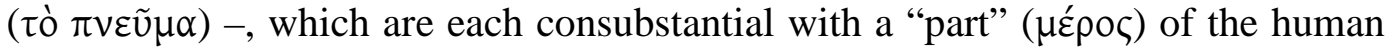

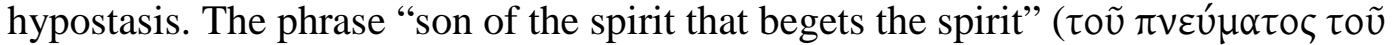

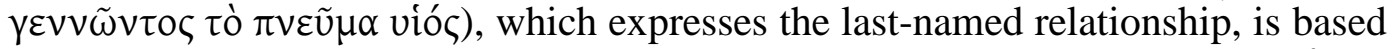
on John 3:6 where Christ avers that "what is born out of the spirit is spirit" ( $\tau$ ò $\gamma \varepsilon$ -

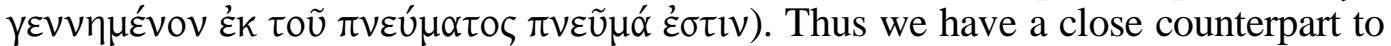
chapter four of book three where Leontius has recourse to the similar verse Hebrews 12:9 and where he also adds the term "son" (viós) to emphasise the genetic relation. Moreover, the human "spirit" ( $\pi \nu \varepsilon \tilde{v} \mu \alpha)$ is again part of the human compound and therefore cannot refer to an additional endowment with the Holy Spirit but must be equated with the soul. This allows us to conclude that Leontius wishes his readers

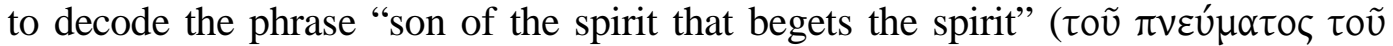

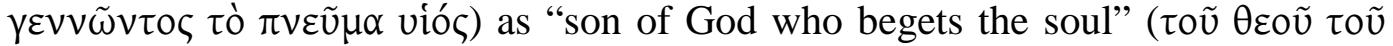

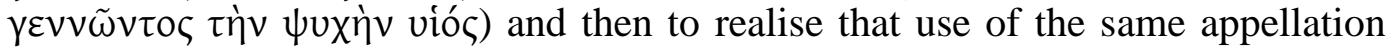
establishes consubstantiality between the divine progenitor and its offspring.

Accordingly, the human parents should then again only be causes of the body. In the first chapter of the second book this point is not made explicit but it can be inferred from the Biblical reference text and from other related passages. In John 3:6 the statement about the spirit is complemented with a statement about the flesh,

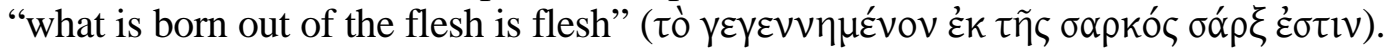
The term "flesh" is ambiguous since it can refer to the complete human being, but in the passage under discussion there can be no doubt that it only denotes the body. This can be seen from chapter seven of book four where we find another list of three progenitors of a human being, in this case the Biblical personage Timothy:

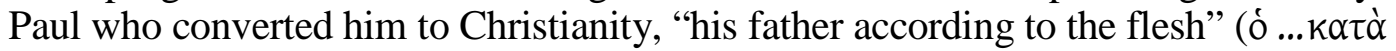

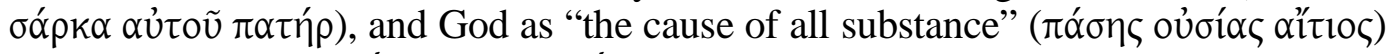

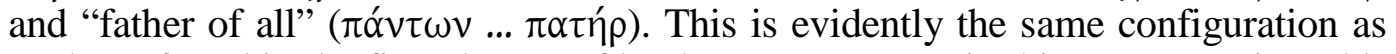
we have found in the first chapter of book two. However, in this case Leontius adds the clarification: "The first begot him as a similar one according to faith, the second

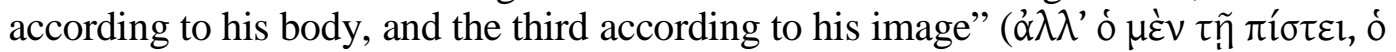

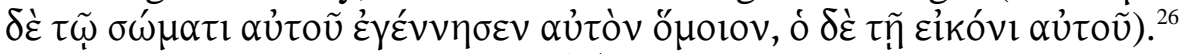

The substitution of "flesh" ( $\sigma \alpha \alpha \rho)$ with the unequivocal "body" ( $\sigma \tilde{\omega} \mu \alpha)$ shows clearly that the former term, too, refers solely to the physical aspect of a human being. ${ }^{27}$ Thus we can conclude that Leontius had developed a consistent framework, which he then repeatedly reproduced in his treatise Contra Nestorianos.

So far we have focused on two genetic relationships, one between God and the human souls, and one between the bodies of human parents and the bodies of their children, both of which establish consubstantiality. This juxtaposition is evidently at the centre of Leontius' argument, because it permits him to point to the human

\footnotetext{
${ }^{26} \mathrm{CN}$, IV.7, $P G, 86,1664 \mathrm{D} 1-3$.

${ }^{27}$ Indeed, the same point can be made as regards the phrase "the father of the spirits" (ó $\pi \alpha \tau \dot{\eta} \rho$

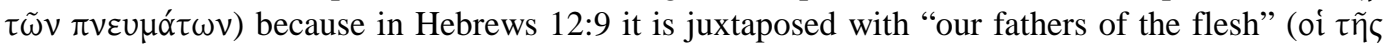

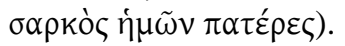

Dirk Krausmüller, "Human Souls as Consubstantial Sons of God: The Heterodox Anthropology of Leontius of Jerusalem," in: Journal for Late Antique Religion and Culture 4 (2010) 43-67; ISSN: 1754-517X; Website: http://www.cardiff.ac.uk/clarc/jlarc
} 
compound as a parallel for the composite Christ. However, in the first chapter of the second book and in chapter seven of book four this straightforward picture is complicated by an additional reference to Abraham and Paul where the relationship is clearly not genetic. In order to understand why Leontius mentions these two figures we need to consider the position of his adversary: the Nestorian had referred to Abraham and Paul in order to support his claim that when the Bible speaks of more than one "father" of a human being, the additional "fathers" are not further progenitors, because the term is merely used as a metaphor. I would therefore suggest that Leontius intends to subvert this distinction by focusing on the fact that Abraham and Paul are human beings and therefore consubstantial with all other human beings, even if they are not their direct progenitors. By doing so he could remove one of the mainstays of the Nestorian's argument, namely that when Scripture describes the relationship between the human being Jesus and the divine Father in genetic terms, this must also be discounted as metaphorical speech. ${ }^{28}$

Indeed, the assertion that souls are consubstantial with God can also be understood as a response to a Nestorian argument. In chapter thirty-two of book four the Nestorian concludes from John 3:6 that an ordinary Christian is an adoptive son of God through baptism and instruction and "is not begotten out of the substance of

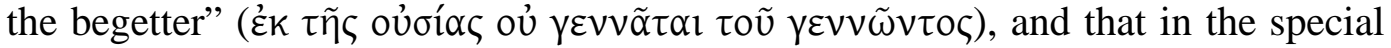
case of the incarnation the man Jesus can therefore only be endowed with the Spirit but not be compounded with the Word. In order to counter this argument Leontius clearly felt the need to identify the "spirit" with the soul, which is hypostatically united with the body and can thus provide an analogy for the composition of the divine nature and the human nature in the incarnation. ${ }^{29}$

With his insistence on a genetic relationship between God and the human souls, which establishes their consubstantiality, Leontius deviates radically from the Christian mainstream. Earlier exegetes of Hebrews 12:9 had stressed that in this case fatherhood cannot be understood in the strict sense of the word: in his Commentary on Isaiah Cyril states that the formula "father of the spirits" ( $\pi \alpha \tau \eta \dot{\eta} \rho \tilde{\omega} v$

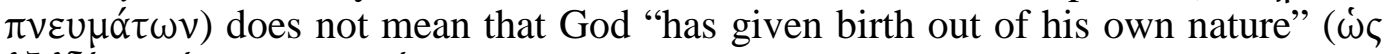

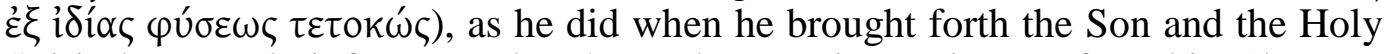
Spirit, but merely informs us that the souls come into existence from him "by way of creation" ( $\delta \eta \mu l o u \rho \gamma \iota \kappa \tilde{\omega} \zeta) .{ }^{30}$ This raises the question: how does Leontius conceive of the relationship between the soul and the divine Word? In order to find an answer I will now turn to chapter eighteen of book one. There Leontius is confronted with the Nestorian claim that the salvation of mankind is achieved through the "good

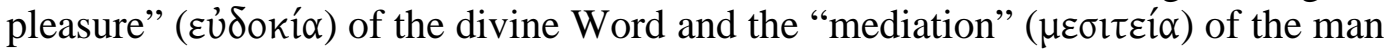
Jesus and that it is therefore unnecessary to posit a composition of the substance of the Word with the substance of a human being. In order to refute this position Leontius draws a parallel with creation. He starts by pointing out that God did not

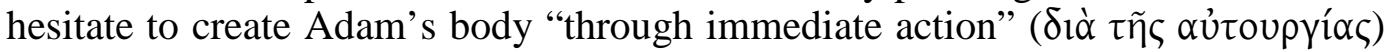
and that there is therefore no reason why he should not have personally recreated the fallen human being. ${ }^{31}$ This is a traditional theme, which is found in writings of

\footnotetext{
${ }^{28} C N$, IV.32, $P G, 86,1697$ A6-7.

${ }^{29} C N$, IV.32, $P G, 86,1697 \mathrm{D} 9-10$.

${ }^{30}$ See Cyril of Alexandria, Commentary in Isaiam prophetam, PG, 70, 1276AB.

${ }^{31} \mathrm{CN}, \mathrm{I} .18, P G, 86,1468 \mathrm{D} 1-1469 \mathrm{~A} 4$.

Dirk Krausmüller, "Human Souls as Consubstantial Sons of God: The Heterodox Anthropo-

logy of Leontius of Jerusalem," in: Journal for Late Antique Religion and Culture 4 (2010) 43-67; ISSN: 1754-517X; Website: http://www.cardiff.ac.uk/clarc/jlarc
} 
both Alexandrian and Antiochene writers who emphasise that human beings are privileged over all other creatures because they owe their existence to a direct act of God. ${ }^{32}$ However, it does little for Leontius' argument that the relationship between God and Adam provides a parallel for the composition of the divine Word with a human nature. If we take God's creation of Adam as a paradigm we only arrive at a scenario where the Word creates a human body for himself whereas the nature of the relationship between the Word and this body is left undefined. It is evident that in order to have an effective parallel for the incarnation Leontius would need to show that the soul in the composite "Adam" corresponds to the divine Word in the composite "Christ"; and this is indeed what he does in the following passage:

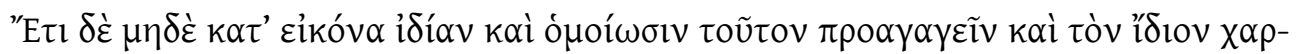

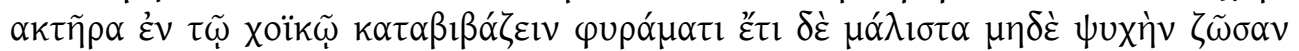

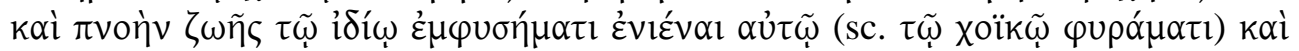

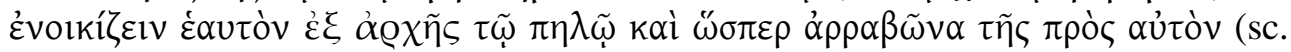

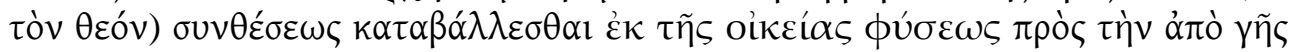
бó $\rho \kappa \alpha .{ }^{33}$

"Moreover, he would not have produced him according to his own image and likeness nor would he have caused his own imprint to descend into the earthly lump. And, above all, he would not have injected into him a living soul and breath of life through his own inbreathing and housed himself in the clay from the beginning and paid down as some earnest of the combination with it (sc. the clay) out of the own nature with the flesh from earth."

In this passage Leontius has again recourse to the two Biblical accounts of the coming to be of Adam, Genesis 1:26: "Let us make man in our image and likeness"

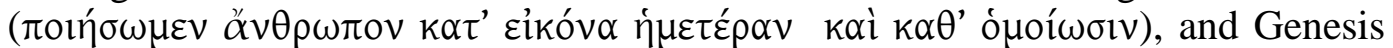
2:7: "And God formed man as dust from the earth and breathed into his face a

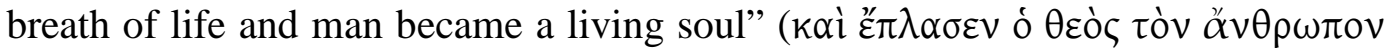

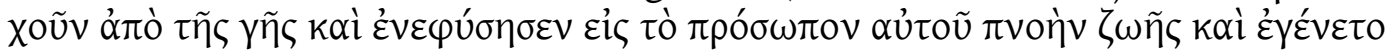

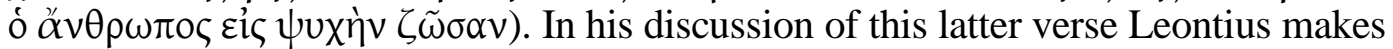
an explicit link between the coming to be of Adam and the incarnation of the Word and he conceptualises the former in terms that go beyond a simple act of creation:

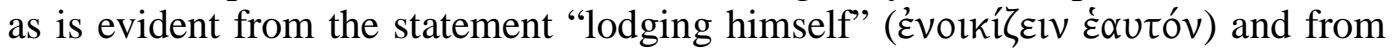

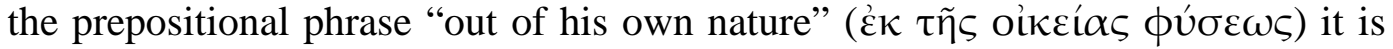
the divinity itself that is infused into Adam, which creates an obvious link with

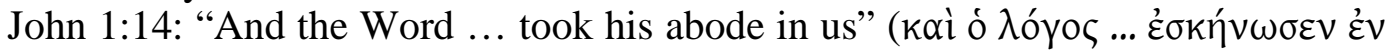
$\eta \dot{\eta} \mu \mathrm{v} v)$. This is clearly a scenario that would be reconcilable with the view that the human soul is of divine origin, which we have encountered in the previously dis-

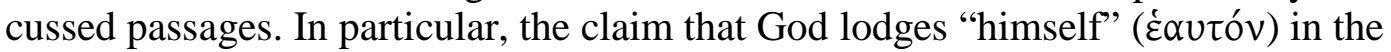
"clay" ( $\pi \eta \lambda o ́ s)$ and the juxtaposition of the two prepositional phrases "out of the

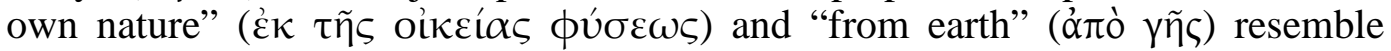
closely the statements we found in Leontius's discussion of the two-fold consubstantiality of human beings.

\footnotetext{
${ }^{32}$ See e.g. Cyril of Alexandria, Glaphyra in Genesin, I, PG, 69, 20B; and Theodore of Mopsuestia, Fragmenta in Genesin, $P G, 66,637 \mathrm{~A}$.

${ }^{33} \mathrm{CN}, \mathrm{I} .18, P G, 86,1469 \mathrm{~A} 4-12$.

Dirk Krausmüller, "Human Souls as Consubstantial Sons of God: The Heterodox Anthropology of Leontius of Jerusalem," in: Journal for Late Antique Religion and Culture 4 (2010) 43-67; ISSN: 1754-517X; Website: http://www.cardiff.ac.uk/clarc/jlarc
} 
As in the passages that we have discussed so far this impression could be substantiated through detailed analysis of the argument. However, in this case I will not immediately turn to Leontius' text but rather start by identifying the exegetical tradition, which provided the starting point for his reasoning, and then proceed to establish how he deviated from this tradition and why he did so. The previous discussion has only considered Patristic authors who took the statement "he breathed

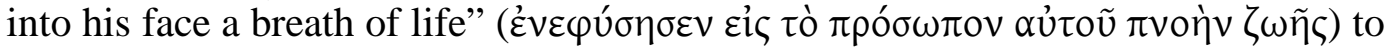
be a reference to the infusion of the soul into Adam's body because this is also how Leontius understands the term in all the passages that we have discussed so far. However, this was not the only possible interpretation of the first part of Genesis 2:7. Alexandrian theologians made a sharp distinction between this statement and

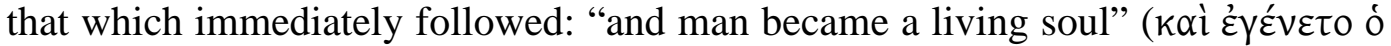

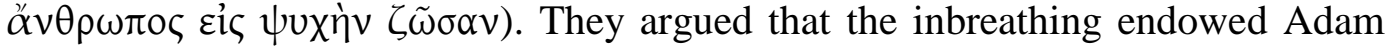
with the gift of the Holy Spirit, which was then lost or at least obscured through the fall and finally returned to human kind by Christ. This view was inspired by the striking similarity between Genesis 2:7 and John 20:22 where we are told that the resurrected Christ appeared in the midst of the Apostles, "breathed on them and

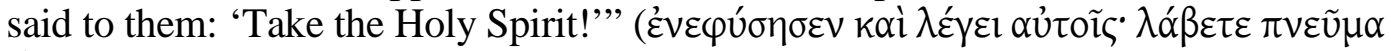
ó $ү 10 v)$. The relation between the two verses is made explicit by many authors. Cyril of Alexandria, for example, states in his Commentary on the Gospel of John that

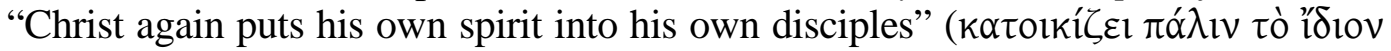

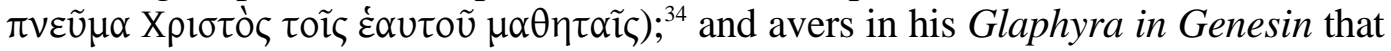
the "inbreathing" of Genesis 2:7 is an act by which God "immediately imprinted an

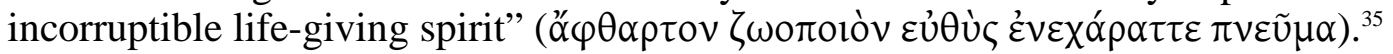

These authors not only express themselves in strikingly similar terms but also appear to have the same concerns as Leontius. They tend to emphasise that it is the very divinity and not some derivative entity that lodges itself in human beings. Gregory of Nyssa, for example, states that studious prayer 'gives great gifts and

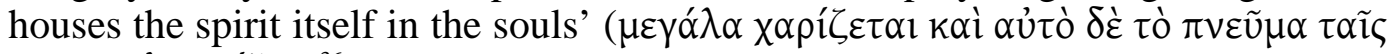

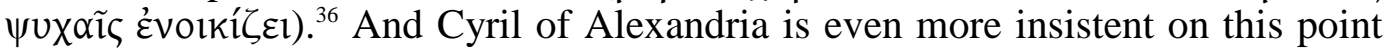
when he concludes in his treatise De sancta Trinitate that the Spirit transforms the

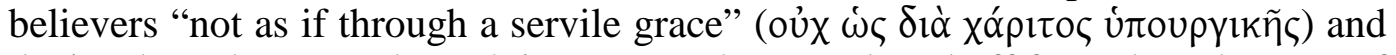
denies that "the grace through it was somehow cordoned off from the substance of

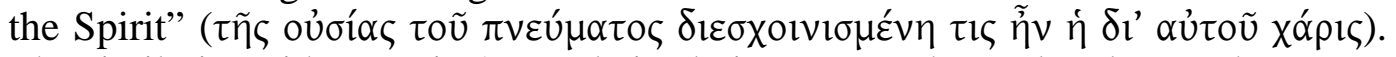
The similarity with Leontius' agenda is obvious: as we have already seen he stress-

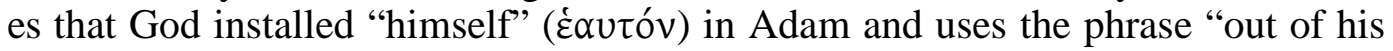

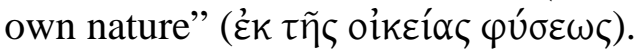

However, a closer look at chapter eighteen of book one reveals some obvious discrepancies between the positions of Leontius and of Cyril of Alexandria. First of all, Leontius identifies the "inbreathing" ( $\dot{\mu} \mu \varphi v ́ \sigma \eta \mu \alpha)$ not with the Spirit but with the Son. This is evident from the context: before he refers to God's "own

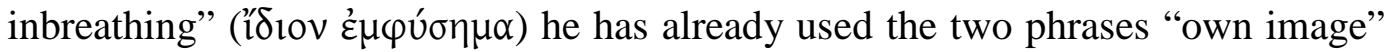

\footnotetext{
${ }^{34}$ Cyril of Alexandria, Commentarius in Iohannem, ed. Pusey, vol. 3, 135; see also Commentary on John, John 12:1, vol. 4, 1097E.

${ }^{35}$ Cyril of Alexandria, Glaphyra in Genesin, I, PG, 69, $20 \mathrm{~B}$.

${ }^{36}$ Gregory of Nyssa, De instituto Christiano, ed. W. Jaeger, Gregorii Nysseni Opera, VIII.1: Opera Ascetica (Leiden, 1952), p. 80, 11. 9-11.

Dirk Krausmüller, "Human Souls as Consubstantial Sons of God: The Heterodox Anthropology of Leontius of Jerusalem," in: Journal for Late Antique Religion and Culture 4 (2010) 43-67; ISSN: 1754-517X; Website: http://www.cardiff.ac.uk/clarc/jlarc
} 


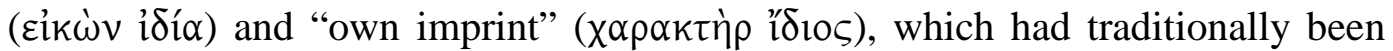
taken to refer to the Son. Since Origen Christian authors had rephrased the Biblical

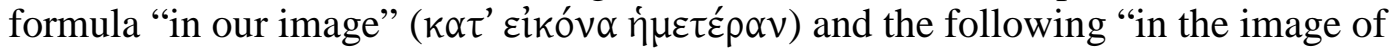

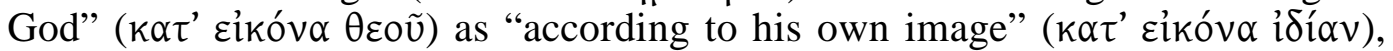
thereby identifying the divine model for the human soul with the Son of God who

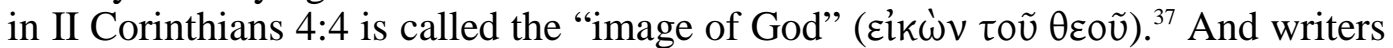
such as Athanasius of Alexandria had referred to the Son as the "own imprint"

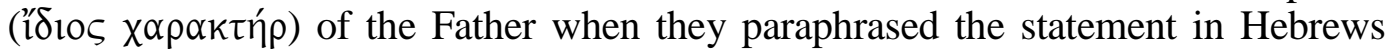
$1: 3$ that the Son is the "imprint of his (sc. God's) hypostasis" ( $\chi \alpha \rho \alpha \kappa \tau \eta \dot{\rho} \tau \tilde{\eta} \varsigma$

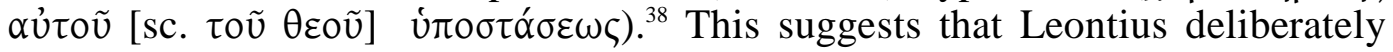
created the series of the three statements in order to insinuate to his readers that he wished the last term not to be identified with the Spirit as was traditional but with the Son. The reason for this manipulation is evident: by substituting the Son for the Spirit Leontius was able to create a much closer parallel with the incarnation where the Son and not the Spirit became man.

A similar reworking of traditional themes can be detected from the way Leontius conceives of the entity with which the divine Son compounded himself. Here it is instructive to compare Leontius' phrase "to inject a living soul and a breath of life into it (sc. the earthy mixture) through his own inbreathing and to house himself at

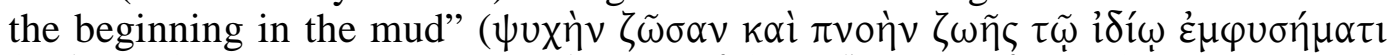

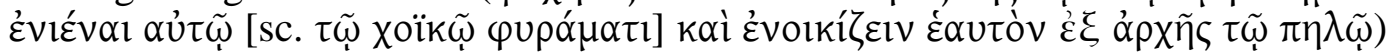
with a similar formula in Cyril's De sancta trinitate, "housing and injecting the spirit into the souls of the faithful and refashioning them through it and in it to the

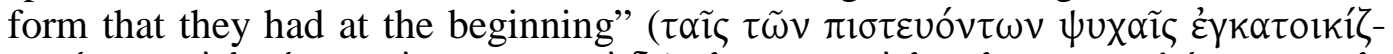

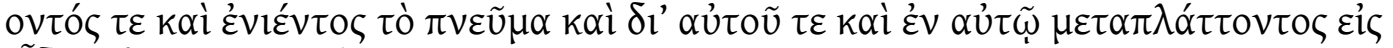

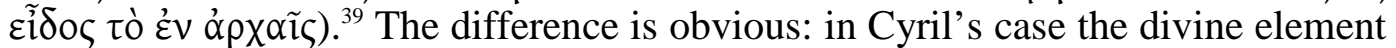
is infused into an already existing soul whereas Leontius mentions "living soul" $(\psi v \times \grave{\eta} \zeta \tilde{\omega} \sigma \alpha)$ as an added feature. At this point one might argue that Leontius uses with "breath of life" ( $\pi \nu \circ \eta \bar{\eta} \zeta \tilde{\eta} \varsigma)$ a second term that might denote the Spirit as a further entity that was also infused into Adam's body. However, against such an interpretation it must be pointed out that he makes no effort to distinguish between the two terms: he simply correlates them, although in the Biblical text they are part of two subsequent and quite distinct statements - "he breathed into his face a breath

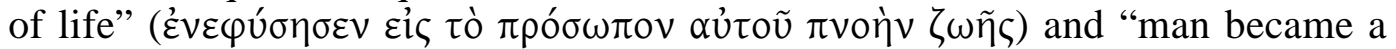

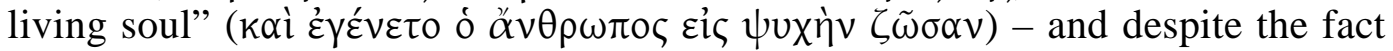
that earlier theologians such as Cyril had insisted that the two statements needed to be kept apart. Indeed we have already seen that Leontius can replace the Biblical $\pi v o \eta$ with $\pi v \varepsilon \tilde{v} \mu \alpha$ in the sense of "soul" when he rephrases Genesis 2:7 as "breathing into it a spirit of life so as to be a living soul" ( $\dot{\mu} \mu \varphi \sigma \sigma \tilde{\omega} \nu \alpha \hat{v} \tau \tilde{\omega} \pi \nu \varepsilon \tilde{v} \mu \alpha$

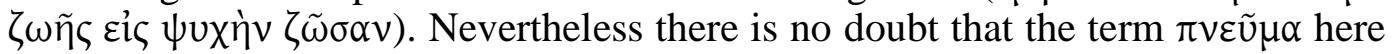
does not refer to the Holy Spirit but to the soul, which is mentioned immediately

\footnotetext{
${ }^{37}$ Athanasius, Orationes tres contra Arianos, PG, 26, 320C; see also Cyril of Alexandria, Glaphyra in Pentateuchum, PG, 69, 465BC.

${ }^{38}$ Athanasius, Orationes tres contra Arianos, PG, 26, 461A; see also Basil of Caesarea, Adversus Eunomium, $P G, 29,753 \mathrm{C}$.

${ }^{39}$ Cyril of Alexandria, De sancta trinitate dialogi VII, PG, 75, 1088C.

Dirk Krausmüller, "Human Souls as Consubstantial Sons of God: The Heterodox Anthropology of Leontius of Jerusalem," in: Journal for Late Antique Religion and Culture 4 (2010) 43-67; ISSN: 1754-517X; Website: http://www.cardiff.ac.uk/clarc/jlarc
} 
afterwards. ${ }^{40}$ This suggests that here, too, "living soul" and "breath of life" are synonymous and that they both denote the soul and also the divinity, since they are taken up again by "himself" ( $\dot{\alpha} \alpha \tau \tau o ́ v)$. And in the same way we will then need to

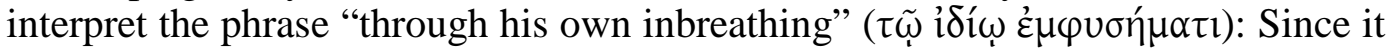
is equated with the divine Son it is also identical with the following reflexive pronoun and can therefore not be materially different from "breath of life" and "living soul". Such interpretation would entail that for Leontius the recipient of the "inbreathing" is not the whole Adam, but merely Adam's body. We have seen that he expresses this view in other parts of Contra Nestorianos and close examination of the passage under discussion reveals that this is also true in this

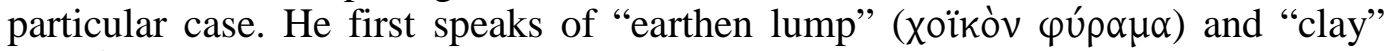
$(\pi \eta \lambda o ́ s)$, which can refer to the whole human being or to the body alone.

However, such a reading is not possible for the statement that Christ created a precedent for his own composition by joining himself "to the flesh from earth"

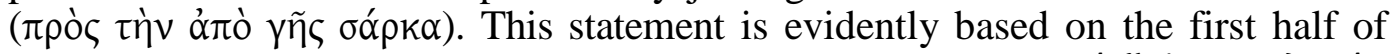

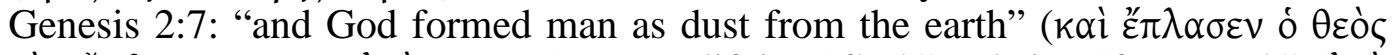

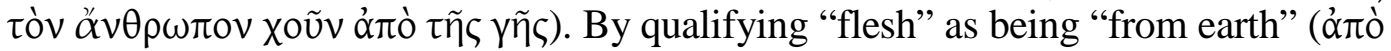
$\gamma \tilde{\eta} \varsigma$ ) Leontius insinuates that "flesh" is to be identified with "dust" ( $\chi \circ \tilde{v} \varsigma)$, which means that it must refer exclusively to the body. ${ }^{41}$ Therefore we can conclude that the "inbreathing", now identified with the divine Son, enters a material body and becomes the soul of the human being Adam.

It is not difficult to see why Leontius strayed from the traditional "Alexandrian" position and substituted the soul for the Holy Spirit. While endowment with the Holy Spirit results in a scenario where the divine substance is present in human beings this presence is nevertheless not a part of human nature: it remains extrinsic to it and can even be lost. Therefore it cannot serve as a parallel for the divine Son if the incarnation is to be conceptualised as a composition and must be replaced by the soul as one part of the human composite.

The comparison of Leontius' argument with traditional Alexandrian exegesis has given us a first insight into the origins of his conceptual framework. However, he was not only influenced by theologians with whom he felt a natural affinity; he was also indebted to the theology of his Antiochene or Nestorian enemies. This can be seen when we focus on the manner in which Leontius seeks to distinguish the coming to be of ordinary human beings from the incarnation of the Word. So far we have only considered similarities between the two events: we have seen that God lodges "himself" ( $\dot{\varepsilon} \alpha \cup \tau o ́ v)$ in Adam and that what he lodges there is "out of

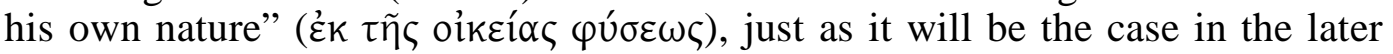
incarnation. However, Leontius also informs us how he wishes us to conceive of the relationship between the two events: he calls the ensouling of Adam a "pledge

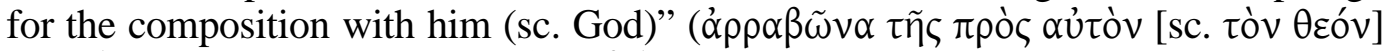
$\sigma \cup v \theta \varepsilon \dot{\sigma \varepsilon} \omega \varsigma)$. In its literal sense $\alpha \rho \rho \alpha \beta \omega ́ v$ refers to a partial payment that a purchaser offers as a security for the delivery of the whole sum that is owed by him, ${ }^{42}$ and

\footnotetext{
${ }^{40}$ See $C N$, III.4, $P G, 86,1612 \mathrm{D} 4-7$.

${ }^{41}$ This is corroborated through comparison with the statement quoted in the previous footnote where the ambiguous term $\sigma \alpha ́ \rho \xi$ is replaced with the unequivocal $\sigma \tilde{\omega} \mu \alpha$.

${ }^{42}$ H.G. Liddell, R. Scott and H.S. Jones, A Greek-English Lexicon (Oxford, 1968), s. v. ó $\rho \rho \alpha \beta \omega ́ v$, earnest-money, caution-money, deposited by the purchaser and forfeited if the purchase is not completed, 2. generally, a pledge, earnest.

Dirk Krausmüller, "Human Souls as Consubstantial Sons of God: The Heterodox Anthropology of Leontius of Jerusalem," in: Journal for Late Antique Religion and Culture 4 (2010) 43-67; ISSN: 1754-517X; Website: http://www.cardiff.ac.uk/clarc/jlarc
} 
this meaning is preserved when the term is used in a metaphorical sense: Christian authors consistently interpret it as denoting a "part" ( $\mu \varepsilon ́ \rho \circ)$ ), which is "incomplete"

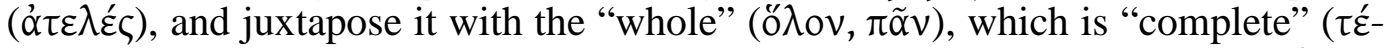
$\lambda \varepsilon 10 v){ }^{43}$ Accordingly, we can rephrase "pledge out of his own nature" ( $\alpha \rho \rho \alpha \beta \tilde{\omega} v \alpha$

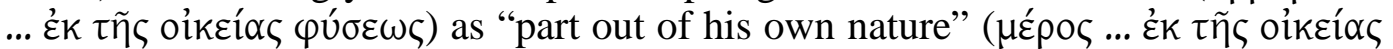
$\varphi v ́ \sigma \varepsilon \omega \varsigma$ ) and we can infer that in Christ's humanity resides the "whole" (ő $\lambda$ ov) of the divinity.

How did Leontius arrive at this conceptual framework? His starting-point was

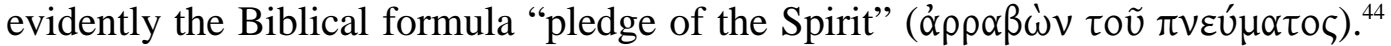
Other Christian authors such as Gennadius of Constantinople had interpreted this formula as "the partial grace of the Spirit" ( bestowed in the wake of the incarnation and had juxtaposed it with the "universal

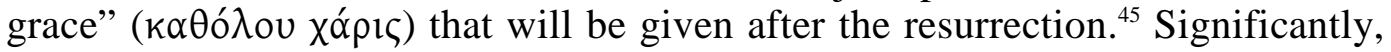
however, the same conceptual framework is employed by Antiochene theologians when they attempt to distinguish between Christ and other virtuous human beings. As I have already mentioned, the Nestorian author put a strong emphasis on the endowment of the man Jesus with the Holy Spirit, which then permitted him to claim that it was not necessary to conceive of the incarnation as a composition in order to safeguard the salvific effects of the incarnation. This endowment of Jesus with the Spirit, however, was conceived in quantitative terms: It was argued that Jesus received the whole Spirit whereas saintly human beings of earlier times only received a part of this Spirit. This notion is set out most concisely by Theodoret of Cyrus in his Haereticarum Fabularum Compendium where it is claimed that God distributed to the prophets the gifts of the Spirit, whereas in the incarnation he gave

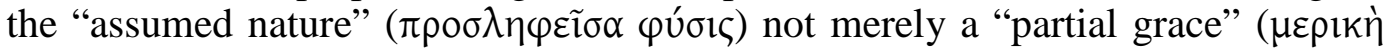

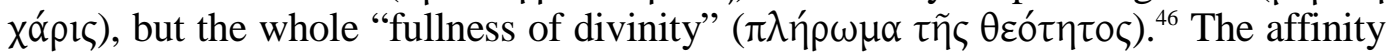
of this view with Leontius' position is evident throughout Contra Nestorianos: in chapter twenty-eight of book four Leontius attempts to distinguish Christ's status from that of Jeremiah and John the Baptist by claiming that Mary gave birth to "the spirit itself" ( $\alpha \dot{\tau} \tau o ̀ ~ \tau o ̀ ~ \pi v \varepsilon \tilde{v} \mu \alpha$ ), which in this context clearly refers to Christ, whereas the latter two figures were anointed in the womb "through participation

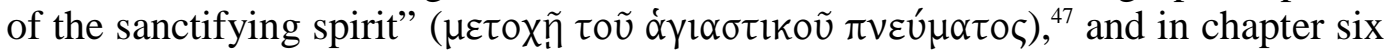
of book five he distinguishes Jesus Christ from other "Jesuses" mentioned in the Bible by claiming that these other "Jesuses" were given that name "because of

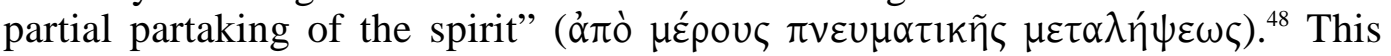
shows that Leontius conceived of the difference between participation in the spirit

${ }^{43}$ See P. Bruns, Den Menschen mit dem Himmel verbinden. Eine Studie zu den katechetischen Homilien des Theodor von Mopsuestia (CSCO, 549, 'Subsidia, 89; Leuven, 1995), 332: "Der Teilaspekt gehort wesentlich zur Natur des Unterpfandes," and note 214 with a list of examples from Theodore and other authors of the fourth and fifth centuries. For a later parallel, see Anastasius of Antioch, Oratio, IV, 14, ed. S. N. Sakkos, Anastasii I Antiocheni opera omnia genuine quae super-

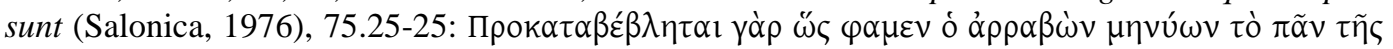

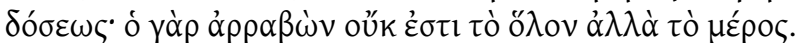

${ }^{44}$ See II Corinthians 1:21-22, and II Corinthians 5:5.

${ }^{45}$ Gennadius of Constantinople, Fragmenta in Epistolam ad Romanos, PG, 85, 1700A.

${ }^{46}$ Theodoret, Haereticarum Fabularum Compendium, V, 23, PG, 88, 532AB.

${ }^{47} C N$, IV $.48, P G, 86,1720 \mathrm{D} 2-11$.

${ }^{48} C N$, V.6, $P G, 86,1732 \mathrm{~A} 7-8$.

Dirk Krausmüller, "Human Souls as Consubstantial Sons of God: The Heterodox Anthropo-

logy of Leontius of Jerusalem," in: Journal for Late Antique Religion and Culture 4 (2010) 43-67; ISSN: 1754-517X; Website: http://www.cardiff.ac.uk/clarc/jlarc 
and reception of "the spirit itself" in terms of part and whole, i. e. in very much the same ways as Antiochene and Nestorian authors did.

Therefore one can argue that Leontius was influenced by the conceptual framework of his opponent, which he then modified to serve his own purposes. The first step that he took was to transpose this model to a protological context. This is not without precedent: Basil of Caesarea, for example, states in his Homiliae super psalmos that by breathing on Adam's face God "deposited a part of his own grace

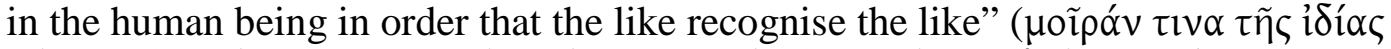

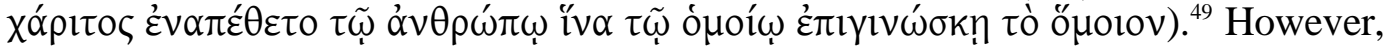
then he parted company with tradition altogether when he replaced the Holy Spirit, which is given to the soul, with the soul itself. The radical nature of this step becomes clear when we consider that not even the position of Cyril and Gregory of Nyssa that the souls were endowed with the substance of the Holy Spirit was universally accepted. Cyril of Jerusalem, for example, when interpreting the Pauline

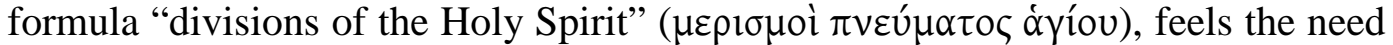
to add the comment that "it is not the Spirit that is divided but the grace through

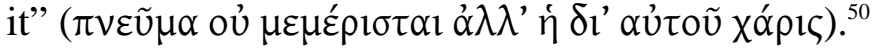

At this point we can recapitulate. Through the reworking of traditional themes Leontius creates a framework where the divine Son is present in the human being not as an additional endowment but rather as the soul and where the human souls become parts of the divine nature of the Son, which have been partitioned off from him. As I have stated, Leontius developed this model because it allowed him to counter the Nestorian contention that a composition of an uncreated entity and a created entity is impossible for he could then claim that there existed a precedent in Adam's coming to be. This creates the impression that Leontius developed a heretical anthropology in order to defend an orthodox Christology. However, a closer look at his understanding of the incarnation shows that this is not the case. His reinterpretation of the coming to be of Adam as the composition of a part of the Son with a material body provides a parallel not so much for the traditional understanding of the incarnation as a composition between the Son and a humanity consisting of soul and body, but for a scenario where the Son takes the place of the soul within the human compound: as we have seen, the only difference between the coming to be of Adam and the incarnation lies in the fact that Adam's soul is a "part" of the Son, whereas Christ's soul is the "whole" Son. This is evident from the phrase "to deposit so-to-speak a pledge for the composition with him out of his

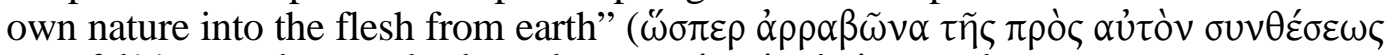

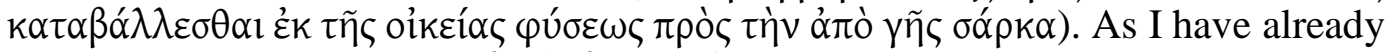
pointed out, the expression $\tau \dot{\eta} v$ ả $\pi$ ò $\gamma \tilde{\eta} \varsigma \sigma \alpha ́ \rho \kappa \alpha$ is clearly based on the phrase "dust

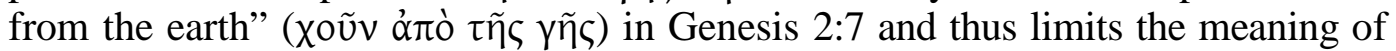
"flesh" to the material body into which the divine "inbreathing" is then infused. In its context this phrase refers to the coming to be of Adam, but the choice of the word $\sigma \alpha ́ \rho \xi$ alludes to John 1:14: "and the Word became flesh and took his abode

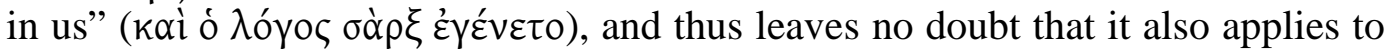
Christ's incarnation for which Adam's coming to be provided a precedent. This

\footnotetext{
${ }^{49}$ Basil of Caesarea, Homiliae super psalmos, PG, 29, 449CD.

${ }^{50}$ Cyril of Jerusalem, Catechesis 17, ch. 12, ed. W.C. Reisch and J. Rupp, Cyrilli Hierosolymorum archiepiscopi quae supersunt opera omnia, 2 vols (Munich, 1848-1860), 11. 21-22.

Dirk Krausmüller, "Human Souls as Consubstantial Sons of God: The Heterodox Anthropology of Leontius of Jerusalem," in: Journal for Late Antique Religion and Culture 4 (2010) 43-67; ISSN: 1754-517X; Website: http://www.cardiff.ac.uk/clarc/jlarc
} 
permits us to conclude that for Leontius the human element in the incarnate Son is a mere body, whereas the soul is to be equated the Son himself.

If one wished to play the heresiological game one could say that Leontius here develops an "Apollinarian" Christology. However, the similarity is only superficial, since unlike Apollinaris Leontius extends this model to all other human beings as well. Moreover, there is no sign that he ever drew the conclusion that the traditional Chalcedonian interpretation of the incarnation could be dispensed with. Indeed, he gives the impression that in the incarnate Word the divine is present twice, once as the soul and once as the divinity proper. Chapter nineteen of book one illustrates the problems that this view caused for Leontius' theological position. There he is again confronted with the Nestorian claim that the sinlessness of Jesus cannot be attributed to the union with the Son of God but is the result of Jesus' will and the support of the Holy Spirit since otherwise it would not be a genuine achievement. ${ }^{51}$ He starts his refutation by claiming that in Jesus Christ the spirit plays the same role as does the free will in us since we are justified through the moral choices we make whereas Paul states in I Timothy 3:16 that Christ "was justified in the Spirit"

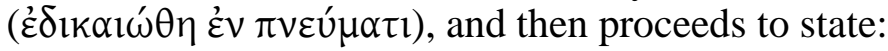

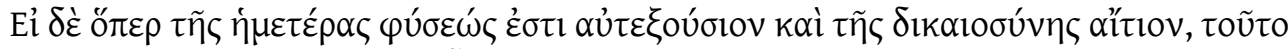

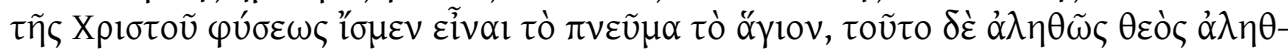

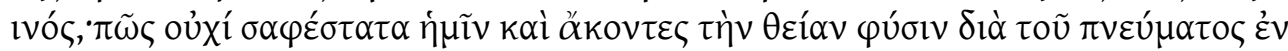

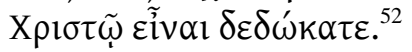

"But if as we know the free will and the cause of the righteousness of our nature correspond to the Holy Spirit of Christ's nature, and this (sc. the Holy Spirit) is truly true God, how then have you not conceded to us even if against your will that the divine nature is in Christ through the spirit."

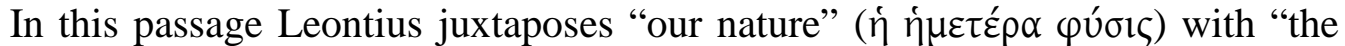

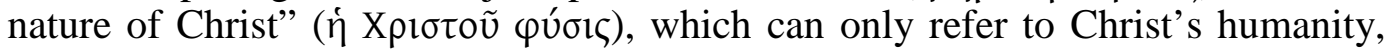
because otherwise the statement would take on a Monophysite character. That Leontius distinguishes the two "natures" from one another in this way is highly suggestive since according to official doctrine there is no difference between the humanity of Christ and the humanity of other human beings. And indeed the strict parallelism suggests that the Spirit belongs to Christ's nature in the same way as the willing soul belongs to the nature of other human beings and that it is therefore part of the human compound. It is not difficult to see why Leontius would have taken this step: if he had not established complete equivalence between the Holy Spirit in Christ and the soul in ordinary human beings he would merely have restated the position of his Nestorian adversary that the human being Jesus acts freely but has the support of the Holy Spirit. However, even such a scenario does not really answer the Nestorian question why a composition between the Word and a human nature should be necessary. After all, so far we have only dealt with the "human" sphere where the Holy Spirit takes the place of the soul. That Leontius was aware of this quandary becomes evident in the immediately following passage:

\footnotetext{
${ }^{51} C N$, I.19, $P G, 86,1472 \mathrm{D} 3-1473 \mathrm{~A} 2$.

${ }^{52} C N$, I.19, $P G, 86,1484 \mathrm{D} 2-1485 \mathrm{~A} 1-6$.

Dirk Krausmüller, "Human Souls as Consubstantial Sons of God: The Heterodox Anthropo-

logy of Leontius of Jerusalem," in: Journal for Late Antique Religion and Culture 4 (2010) 43-67; ISSN: 1754-517X; Website: http://www.cardiff.ac.uk/clarc/jlarc
} 


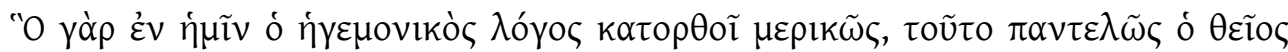
$\lambda$ $\kappa \alpha \tau \omega \dot{\rho} \theta \omega \sigma \varepsilon v .^{53}$

"For what the guiding word achieves in us partially, this has the divine word achieved in Christ completely, in addition to our (sc. word) both of him and of the others who are guiding."

Here finally Christ's achievements are attributed to the divine Word that accedes

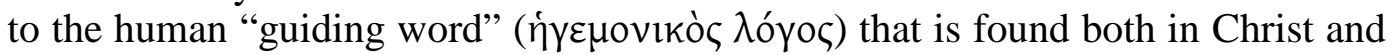
in us, a term that can only refer to the human soul. However, the introduction of the divine component at this point creates severe problems: it is not clear who is responsible for the complete achievement of Christ, which distinguishes him from all other human beings who only manage partial achievements. Since Christ's sinlessness has just been attributed to the Holy Spirit in his human nature the divine Word who enters into a composition with this nature appears to be curiously inert. However, is this really what Leontius wishes to say here? When we look more closely at the sentence we can see that it is construed in a rather curious way. A

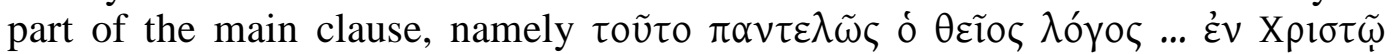
$\kappa \alpha \tau \omega \dot{ } \rho \theta \omega \sigma \varepsilon v$, has an exact counterpart in the preceding relative clause ô $\gamma \grave{\alpha} \rho \dot{\varepsilon v}$

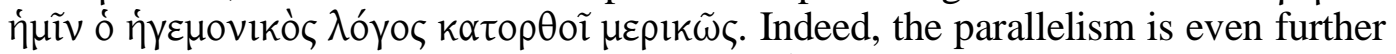

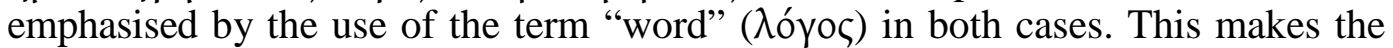

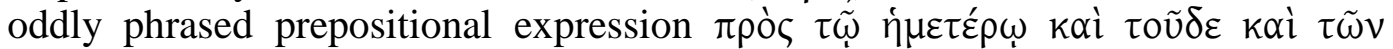

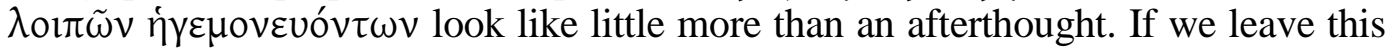
prepositional phrase aside and focus exclusively on the parallel elements a different scenario emerges; for then the "divine Word" ( $\theta \varepsilon \tilde{\imath} о \varsigma$ 人óyos) in Christ is correlated

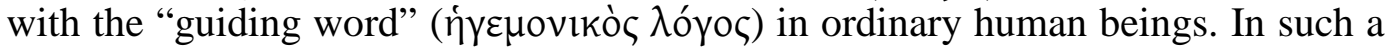
scenario, however, the "divine Word" would no longer be the divine person that enters into a composition with a human nature but rather the Holy Spirit of the previous passage that was there presented as the entity responsible for the moral achievements of this human nature. That Leontius does indeed oscillate between these two models can be seen from the following passage, which concludes the chapter:

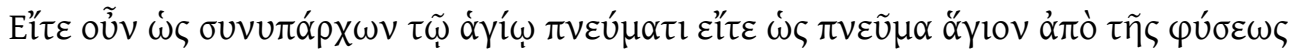

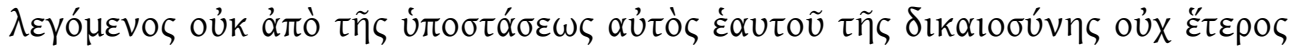

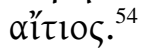

"Whether co-existing with the Holy Spirit or being called "holy spirit" because of the nature and not because of the hypostasis, he himself and not another is cause of his own righteousness."

Here Leontius sketches two alternative scenarios that are meant to explain how the justification of Christ was effected. The first scenario, that the divine Word coexists with the Holy Spirit, corresponds to our first reading of the previous passage

\footnotetext{
${ }^{53} C N, \mathrm{I} .19, P G, 86,1484 \mathrm{D} 2-1485 \mathrm{~A} 3-6$.

${ }^{54} C N$, I.19, $P G, 86,1484 \mathrm{D} 2-1485 \mathrm{~A} 6-8$.

Dirk Krausmüller, "Human Souls as Consubstantial Sons of God: The Heterodox Anthropo-

logy of Leontius of Jerusalem," in: Journal for Late Antique Religion and Culture 4 (2010) 43-67; ISSN: 1754-517X; Website: http://www.cardiff.ac.uk/clarc/jlarc
} 
because the divine Word can only refer to the entity that enters into a composition with the human nature and the Holy Spirit must refer to the entity that is found within the "human" nature. By contrast, the second scenario, that the divine Word is identical with the "holy spirit", identifies the divine Word with the divine entity that is within the human nature, and thus corresponds to our second reading of the previous passage, with the consequence that the hypostasis of the Word as the properly divine component has fallen out of the equation.

From the evidence presented so far it would appear that Leontius developed his heterodox views about the embodied soul and the incarnate Word because of the constraints of the Christological debate and an overdependence on the conceptual framework of his opponent. However, I would argue that these factors can only provide a partial answer to the question why Leontius deviated so radically from the theological mainstream of his time. It seems likely that he developed his conceptual framework because he already held the belief that the human soul is not a created entity that comes into existence simultaneously with or even after the body but instead shows a closer affinity to the divine and shares in its timelessness. This raises the question: what was the intellectual milieu in which Leontius pursued his theological speculations? The most likely answer to this is that he belonged to the Origenist circles of Palestine and that his worldview was influenced by Platonic concepts.

The affinity between Leontius' speculations and the views of representatives of a Platonising interpretation of the Christian faith is striking. As I have already pointed out in the previous discussion, Gregory of Nyssa asserts that the human intellect is in the likeness of God because it is "the outflow out of the divine in-

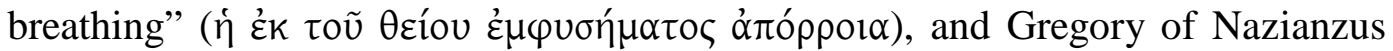
claims that the human souls were "a part of God that had flowed from above"

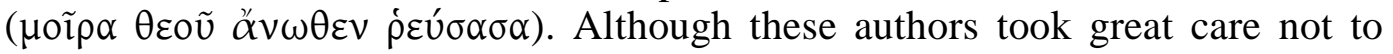
attribute to the soul a divine status in the strict sense of the word, they tended to eschew clear references to a creation of the soul out of nothing. Therefore one can formulate the hypothesis that Leontius merely emphasised latent tendencies within the Origenist tradition and that he did so because his Christological argument required him to find an exact parallel for the incarnation where one component, the Son, was divine in the strict sense of the word.

This hypothesis can be substantiated when we turn to chapter twelve of book one. There the Nestorian author argues that whatever enters into a composition does so in order to draw profit from it. Leontius rejects this position and claims instead that God composed himself with man out of consideration for inferior beings. As so much of Leontius' polemic, this argument is based on a wilful misunderstanding of his opponent's position, who would have readily agreed that God did not profit from the incarnation and only questioned the specific point that the incarnation must be conceived of as a composition. Significantly Leontius does not address this point at all in his argument but instead offers several examples for altruistic behaviour beginning with the Son of God himself:

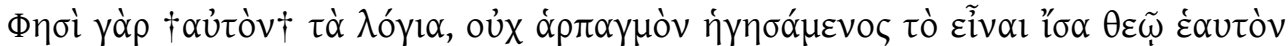

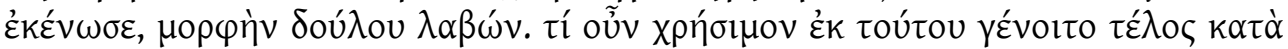

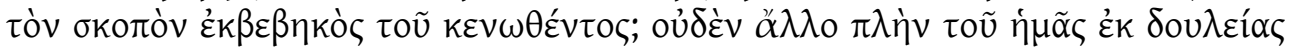

Dirk Krausmüller, "Human Souls as Consubstantial Sons of God: The Heterodox Anthropology of Leontius of Jerusalem," in: Journal for Late Antique Religion and Culture 4 (2010) 43-67; ISSN: 1754-517X; Website: http://www.cardiff.ac.uk/clarc/jlarc 


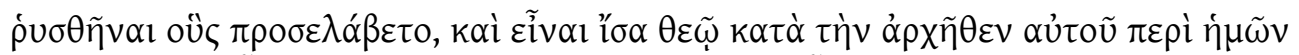

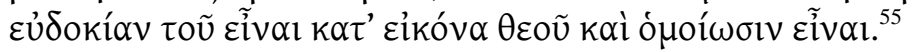

"For Scripture says †about him † that he did not regard being like God as something to be snatched but voided himself, having taken the form of a servant. What profitable end, then, could possibly accrue from this, after it had come to pass according to the plan of him who had been voided? None other but that we whom he took to himself be rescued from servanthood and that we be like God according to his original good pleaure concerning us that we be according to the image and likeness of God."

In this passage Leontius makes the point that the incarnation was a selfless act of the Son of God with the purpose of liberating human beings from their fallen condition and of restoring them to their original state. The passage is a patchwork of Biblical references: for the incarnation Leontius quotes from Philippians 2:6-7: "who being in the form of God did not regard to be like God as something to be snatched but voided himself, having taken the form of a servant, having come to

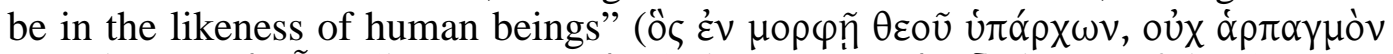

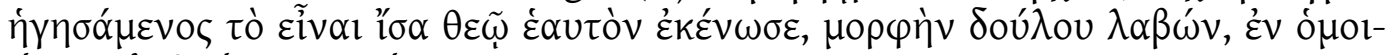

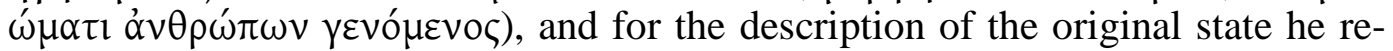
fers to Genesis 1:26: "Let us make a human being in our image and likeness"

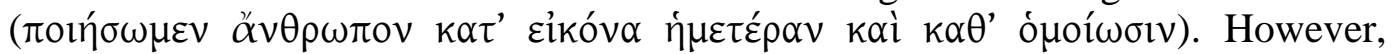
rather than using these quotations side by side he merges them to create one overarching conceptual framework. The context shows clearly that Leontius makes a straightforward equation of "being like God" ( $\varepsilon \tilde{\tilde{I}} v \alpha \iota$ lै $\sigma \alpha \theta \varepsilon \tilde{\omega})$ with "being in the

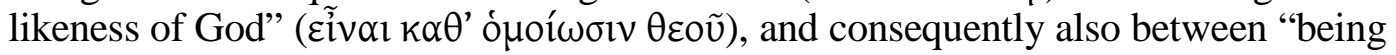

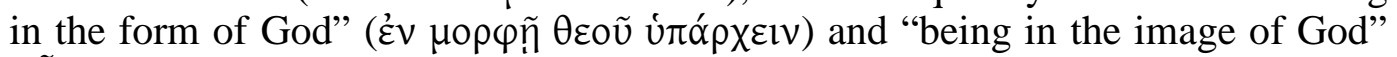

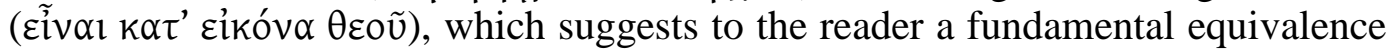
between the two sets of statements, in particular since the characterisation of God's salvific work as a rescue "from servitude" ( $\varepsilon \kappa ~ \delta o u \lambda \varepsilon i ́ \alpha \varsigma)$ implies that human beings

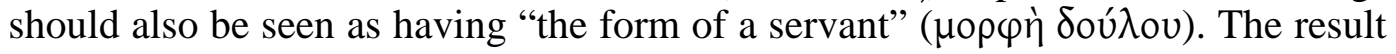
is a quite extraordinary deviation from traditional orthodox exegesis of Philippians 2:6-11. Despite many disagreements on the finer points of interpretation most authors took it for granted that the subject shifts in the course of the statement: the original state and the following descent were seen as referring to Christ's natural divinity and only the ensuing exaltation was interpreted as referring to his assumed humanity. By contrast, Leontius creates a circular framework within which human beings originally enjoyed the same status as "Christ" and made the same descent as him only to be exalted again together with him.

When we look for authors who could have inspired this exegesis of Philippians 2:6-7, we find the closest counterpart in Origen. According to an excerpt from a letter by Theophilus of Alexandria, which is preserved in Theodoret's Eranistes, Origen had distinguished the Son from Christ's soul, arguing that "his soul was

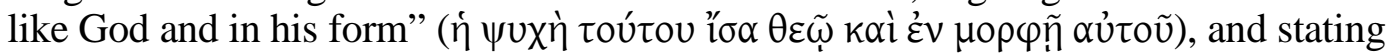
that it was the soul "that had emptied itself and had taken the form of the servant"

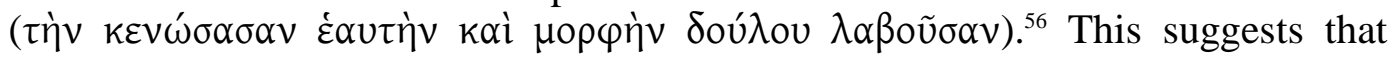

\footnotetext{
${ }^{55}$ CN I.12, PG, 86, 1449A13-B6.

${ }^{56}$ Theophilus of Alexandria, Second Paschal Letter, in Theodoret, Eranistes, II, PG, 83, 197C. Dirk Krausmüller, "Human Souls as Consubstantial Sons of God: The Heterodox Anthropology of Leontius of Jerusalem," in: Journal for Late Antique Religion and Culture 4 (2010) 43-67; ISSN: 1754-517X; Website: http://www.cardiff.ac.uk/clarc/jlarc
} 
Leontius was influenced by the Origenist belief that human souls had originally been pure intellects in close communion with God and had then fallen and become embodied, with the exception of the intellect associated with the Son of God, which voluntarily descended to the world of matter in order to save the fallen. Such interpretation can be further substantiated when we consider the phrase "according to

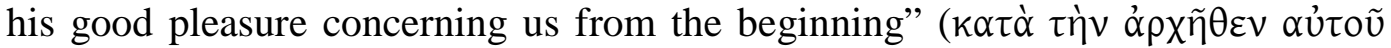

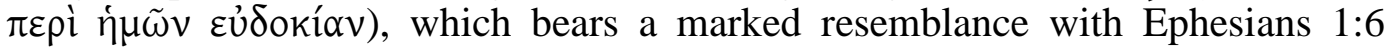

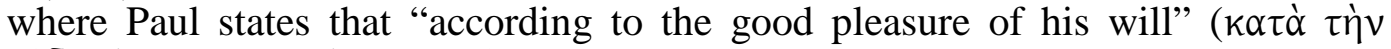

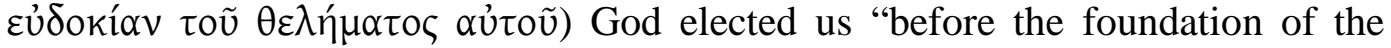

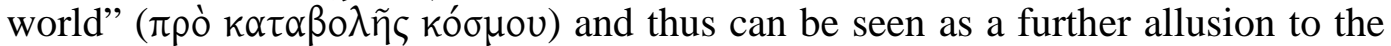
pre-existence of the souls. However, at the same time it is clear that this model has undergone fundamental modifications. As we have seen Leontius develops this theme in order to prove the Chalcedonian point of view that the incarnation must be understood as a composition of the Word with a human nature. Accordingly the agent of Philippians 2:6-11 can no longer be the soul of Christ but must be the Son of God. It is evident that this shift has implications for the status of the souls of the human beings whose salvation the incarnation was to effect: the symmetry of the argument requires that they would then also need to be fully divine. The only element that does not seem to accord with this interpretation is Leontius' assertion that human beings had their primeval likeness with God "according to his good

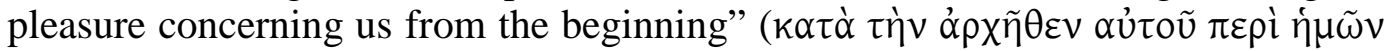

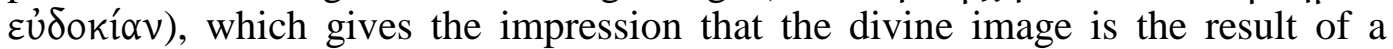
divine act of will. However, this comment is not as unequivocal as it first seems because it could refer to the decision of God to separate from his own substance the elements that were then to become the souls. Chapter twelve of book one thus suggests that Leontius started out as an Origenist and was then carried away by the constraints of the Christological debate, which forced him to formulate a much more extreme position.

Leontius was without doubt fully aware of the fact that he deviated radically from the consensus that had been established in previous centuries; otherwise he would not have exploited terminological and conceptual ambiguities and made terminological substitutions in order to create arguments that at first sight appear entirely orthodox. However, it is noticeable that such caution does not extend to every part of his work. In the previous discussion we have come across several passages where he makes quite explicit statements that his contemporaries would surely have immediately identified as utterly heretical. This raises the question: how could Leontius hope to escape condemnation and persecution? After all, it is a well-known fact that Origenists whose views were considerably less outré than Leontius' had been denounced as heretics at the Second Council of Constantinople and had then seen their writings destroyed by the authorities, with the result that they are now lost in the Greek original and are only known from Syriac translations.

An explanation may present itself when we consider the historical context in which Leontius wrote. In a previous article I have dated Contra Nestorianos to the seventh century and have argued that it most likely postdates the Persian sack of Jerusalem. ${ }^{57}$ This means that Leontius may well have been active during the Persian

\footnotetext{
${ }^{57}$ See my article "Leontius of Jerusalem, a theologian of the 7th century," Journal of Theological Studies, 52 (2001), pp. 637-657.

Dirk Krausmüller, "Human Souls as Consubstantial Sons of God: The Heterodox Anthropology of Leontius of Jerusalem," in: Journal for Late Antique Religion and Culture 4 (2010) 43-67; ISSN: 1754-517X; Website: http://www.cardiff.ac.uk/clarc/jlarc
} 
occupation of Palestine or even after the Muslim conquest of the East. It is obvious that during these two periods the official church could not rely on the state to enforce its own theological positions as it had done in the previous centuries. Therefore one might argue that Leontius availed himself of the newly found freedom in order to voice his radical ideas, in particular since similar views are expressed in writings of other authors of the time. ${ }^{58}$ Anastasius of Sinai, for example, who lived in the second half of the seventh century, wrote a Speech on the Divine Image, which contains the following passage about the origin of the soul:

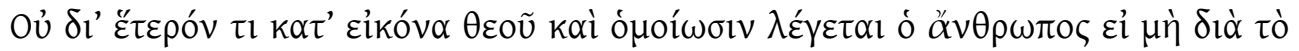

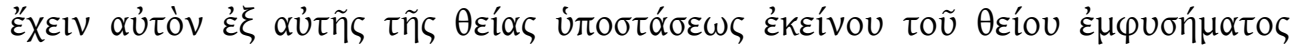

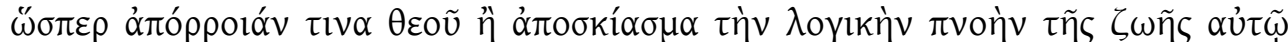

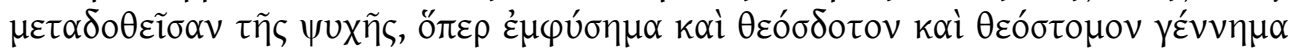

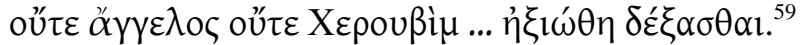

"For no other reason is the human being called according to the image and likeness of God than because of his having it from the divine hypostasis itself of that divine inbreathing, like an outflow of God or a shading-off, having given the rational breath of life to the soul, which inbreathing and god-given and god-mouthed offspring neither angel nor Cherubim ... was deigned worthy to receive."

Here is not the place to embark on an in-depth interpretation of this passage. However, even a cursory reading reveals a marked similarity with Leontius' position: the soul is described as an outflow of God and as being out of the divine inbreathing, which is characterised as a hypostasis and as an offspring of God. This shows that other authors in the seventh century could make exalted statements about the soul and suggests that Leontius may have been a less isolated figure than he now seems to be.

At this point we can summarise the results of our discussion. At the beginning of this article I showed that in his treatise Contra Nestorianos Leontius identifies the soul in the compound Adam with the "divine inbreathing" and that he characterises the "inbreathing" itself with as an emanation from God. I argued that he took this step because he wished to counter the Nestorian claim that a composition between an uncreated and a created entity is impossible: by interpreting the coming to be of Adam as just such a composition he could claim that the incarnation was only one instance of a widespread phenomenon. In a second step I then demonstrated that Leontius defended the twofold consubstantiality of the incarnated Christ by drawing a parallel with the human compound where the human parents are only the causes of the bodies while the souls have God as their father. Through close reading of several passages I attempted to show that Leontius considered God and

\footnotetext{
${ }^{58}$ Indeed, the same may have been true for the Nestorian author whose treatise Leontius attempted to refute. The Nestorian treatise, which most likely dates to the early seventh century, is the only known Greek exposé of a strict Nestorian position that can be dated after Chalcedon; see my article "Conflicting anthropologies in the Christological discourse at the end of Late Antiquity: the case of Leontius of Jerusalem's Nestorian adversary," Journal of Theological Studies, 56 (2005), pp. 413-47.

${ }^{59}$ See Anastasius of Sinai, Sermo II, c. 4, ed. Uthemann, Anastasii Sinaitae Sermones duo, p. 48, 11. 45-52.

Dirk Krausmüller, "Human Souls as Consubstantial Sons of God: The Heterodox Anthropology of Leontius of Jerusalem," in: Journal for Late Antique Religion and Culture 4 (2010) 43-67; ISSN: 1754-517X; Website: http://www.cardiff.ac.uk/clarc/jlarc
} 
the souls to be consubstantial and that he understood their relationship as a genetic one in the strict sense of the word. Having set out the conceptual framework within which Leontius made his case for a Chalcedonian Christology I then proceeded to show that one of his starting points was the traditional view that Adam's soul was endowed with the Holy Spirit itself and not just with a derivative grace. This model had the advantage that it located "God" in the human being but the disadvantage that this presence remained extrinsic to the human compound. To make it function as a precedent for the incarnation of the Word Leontius therefore introduced two modifications: he substituted the Son for the Spirit and he reduced the human nature to the body, thereby indicating that the soul must be divine. In order to distinguish the case of Christ from that of Adam and other human beings he employed the Biblical motif of the "pledge", which was traditionally used to contrast the partial spiritual endowment of the believers in this world with their complete spiritual endowment in the world to come but which he now applied to Adam and Christ. This permitted him to claim that in Adam the Son was only present partially whereas in Christ he was present completely. These modifications led to a further deviation from the theological mainstream: not only was the soul no longer a creature but instead a part of the divine; the incarnation was also no longer conceptualised as the composition of the divine Word with a human nature consisting of body and soul but rather as a composition of the divine Word as soul and a human body, with the consequence that the properly divine component of traditional Christology could no longer be given a satisfactory role in the salvation of mankind. One reason for this shift was obviously a too great dependence on the conceptual framework of his Nestorian opponent whose focus had been on the endowment of the human being Jesus with the Holy Spirit, who thus assumed a crucial role in the incarnation. Leontius accepted this framework, as well as the Nestorian custom to see the difference between the Spirit in Jesus and the Spirit in other human beings in quantitative terms, and merely modified it by identifying the Holy Spirit with the Son on the one hand and with the soul on the other. However, the constraints of the Christological debate and overdependence on the conceptual framework of his opponent can only provide a partial answer to the question why Leontius deviated radically from the theological mainstream. It is evident that he would only have developed his views if he had already held the belief that the human soul is not a created entity that comes into existence simultaneously with or even after the body but instead shows a closer affinity to the divine and shares in its timelessness. His interpretation of Philippians 2:6-7 suggests that Leontius was a latter-day Origenist who could express his ideas more freely than his forebears because the political circumstances of the early seventh century made enforcement of orthodoxy impossible in the Eastern provinces. 